366135 FAst Renatore 3-10 AN-7671 CrB 7mme

DR. $1746 d$

ANL-7671

Argonne National Laboratoru

CONVERSION OF URANIUM DIOXIDE TO URANIUM CARBIDE IN AN INDUCTION PLASMA TORCH REACTOR

by

D. Ramaswami, J. Pavlik, and A. A. Jonke 
The facilities of Argonne National Laboratory are owned by the United States Government. Under the terms of a contract (W-31-109-Eng-38) between the U. S. Atomic Energy Commission, Argonne Universities Association and The University of Chicago, the University emplays the staff and operates the Laboratory in accordance with policies and programs formulated, approved and reviewed by the Association.

\section{MEMBERS OF ARGONNE UNIVERSITIES ASSOCIATION}

The University of Arizona

Carnegie-Mellon University

Case Western Reserve University

The University of Chicago

University of Cincinnati

Illinois Institute of Technology

University of Illinois

Indiana University

Iowa State University

The University of Iowa
Kansas State University The University of Kansas

Loyola University

Marquette University

Michigan State University

The University of Michigan

University of Minnesota

University of Missouri

Northwestern University

University of Notre Dame
The Ohio State University

Ohio Univer sity

The Pennsylvania State University

Purdue University

Saint Louis University

Southern Illinois University

The University of Texas at Austin

Washington University

Wayne State University

The University of Wisconsin

\section{NOTICE}

This report was prepared as an account of work sponsored by the United States Government. Neither the United States nor the United States Atomic Energy Commission, nor any of their employees, nor any of their contractors, subcontractors, or their employees, makes any warranty, express or implied, or assumes any legal liability or responsibility for the accuracy, completeness or usefulness of any information, apparatus, product or process disclosed, or represents that its use would not infringe privately-owned rights

Printed in the United States of America Available from

National Technical Information Service

U.S. Department of Commerce

Springfield, Virginia 22151

Price: Printed Copy \$3.00; Microfiche $\$ 0.65$ 


\section{DISCLAIMER}

This report was prepared as an account of work sponsored by an agency of the United States Government. Neither the United States Government nor any agency Thereof, nor any of their employees, makes any warranty, express or implied, or assumes any legal liability or responsibility for the accuracy, completeness, or usefulness of any information, apparatus, product, or process disclosed, or represents that its use would not infringe privately owned rights. Reference herein to any specific commercial product, process, or service by trade name, trademark, manufacturer, or otherwise does not necessarily constitute or imply its endorsement, recommendation, or favoring by the United States Government or any agency thereof. The views and opinions of authors expressed herein do not necessarily state or reflect those of the United States Government or any agency thereof. 


\section{DISCLAIMER}

Portions of this document may be illegible in electronic image products. Images are produced from the best available original document. 
ANL-7671

Reactor Technology

\author{
ARGONNE NATIONAL LABORATORY \\ 9700 South Cass Avenue \\ Argonne, Illinois 60439
}

\title{
CONVERSION OF URANIUM DIOXIDE \\ TO URANIUM CARBIDE IN AN INDUCTION PLASMA TORCH REACTOR
}

by

D. Ramaswami, J. Pavlik, and A. A. Jonke

Chemical Engineering Division

\section{LEGAL NOTICE}

This report was prepared as an account of work This report Wovernment. Neither the United States nor the United States Atomic Energy the United States nor the their employees, nor any of Commission, nor any of their employees, nor any of their contractors, subcontractors, or their employees, makes any warranty, express or implied, or assumes any legal liability or responsibility for the accuracy, comlegal hability or fuspos of any information, apparatus, pleteness or usefulness of any informatents that its use would not infringe privately owned rights.

August 1970 
-

4

- 
TABLE OF CONTENTS

$\underline{\text { Page }}$

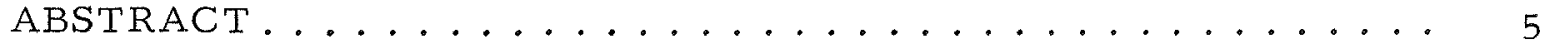

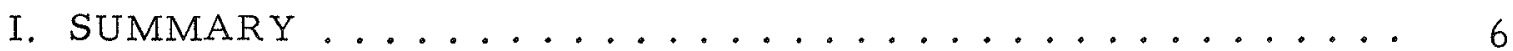

II. INTRODUCTION. ......................... 7

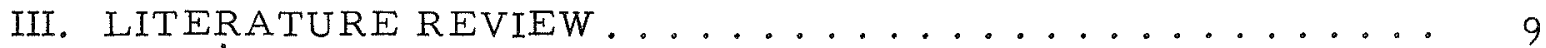

A. Spheroidization Studies Using Induction Plasma Torches .. 9

B. Synthesis and Spheroidization of Uranium Carbides ..... 10

C. Expected Performance of Plasma Torch ........... Il

IV. EQUIPMENT AND OPERATING PROCEDURE ......... 12

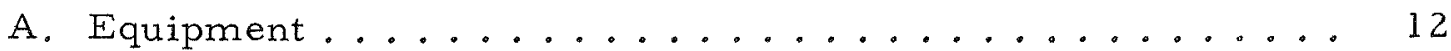

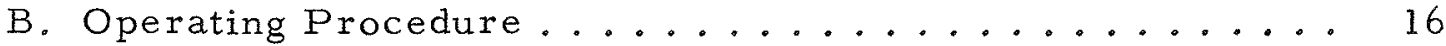

V. RESULTS AND DISCUSSION ................. 17

A. Formation of Carbide Spheres ................ 18

B. Utilization of Carbon in Chemical Reaction and Production Rates of Carbide.................... 19

C. Identification of Gaseous and Solid Products......... 21

D. Process Scale-up Considerations .............. 22

APPENDIXES

A. Preliminary Runs Using Granular Alumina ........ 24

B. Runs with $\mathrm{UO}_{2}-$ Graphite Agglomerates .......... 27

C. Performance of Equipment Components........... 29

ACKNOWLEDGMENTS $\ldots \ldots \ldots \ldots$

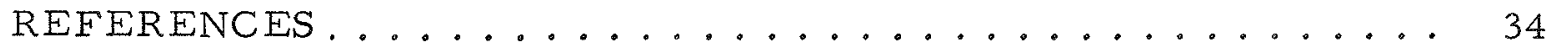




\section{LIST OF FIGURES}

No.

$\underline{\text { Title }}$

$\underline{\text { Page }}$

1. Conversion of $(\mathrm{U}, \mathrm{Pu}) \mathrm{O}_{2}$ to Carbide Spheres in an Induction

Plasma Torch Reactor ..................... 8

2. Installation of Plasma Torch for Studying Conversion of

Uranium Dioxide to Uranium Carbide ............. 12

3. Plasma Torch Mounted on Top Flange of Reaction Chamber . . 13

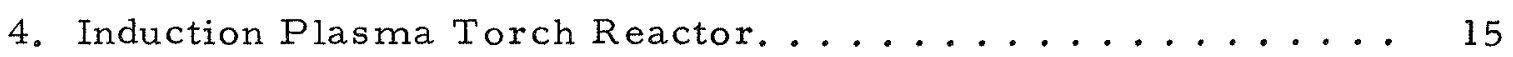

5. Product Receiver Assembly...................... 15

6. Typical Uranium Carbide Spheres Produced in Induction

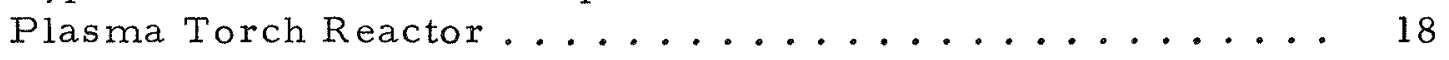

7. Typical Uranium Dioxide-Graphite Agglomerates and Carbide

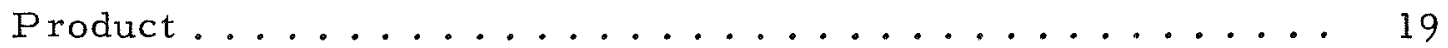

8. Typical Granular and Spheroidized Alumina .......... 25

9. Coating of Fines on Double Flange Holding Plasma Torch and Quartz Plate Insulator during a Run ............. 30

10. Top Portion of Mullite Tube, Showing Breakage due to

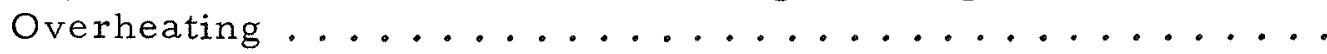

\section{LIST OF TABLES}

No.

Title

$\underline{\text { Page }}$

I. Ranges of Conditions Tested for Conversion of Uranium Dioxide-Graphite Agglomerates to Uranium Carbide in Induction Plasma Torch Reactor.................... 17

II. Utilization of Carbon in Chemical Reactions . . . . . . . . 20

III. Operating Conditions and Results of Preliminary Plasma

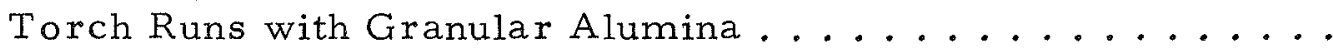

IV. Effect of Diatomic Gas in Argon Plasma on Spheroidization of

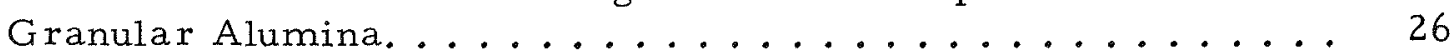

V. Operating Conditions for the Conversion of Uranium DioxideGraphite Agglomerates in the Induction Plasma Torch Reactor.

VI. Analyses of Product Samples .................. 


\section{CONVERSION OF URANIUM DIOXIDE \\ TO URANIUM CARBIDE IN AN \\ INDUCTION PLASMA TORCH REACTOR}

by

D. Ramaswami, J. Pavlik, and $A$. A. Jonke

\section{ABSTRACT}

Exploratory studies wereconducted to determine the feasibility of using an induction plasma torch reactor for converting uranium dioxide-graphite powder agglomerates to uranium carbide spheres. The agglomerates were fed continuously into the tail flame of a $25-\mathrm{kW}(4-\mathrm{MHz})$ induction plasma torch pointed downward. The solid particles were entrained by the tail flame and were directed into a product receiver, where they were separated from the gas stream.

About $20 \%$ of the particles in the product were shiny (with metallic luster) black spheres of 25-50 $\mu \mathrm{m}$. The remainder of the particles had shapes similar to those of feed particles, with some rounding off of sharp corners.

Between 74 and $82 \%$ of the carbon in the feed agglomerates was converted to gas eous and solid products (CO, UC, and alpha- $\mathrm{UC}_{2}$ ). The percent carbon utilization was almost constant, although the $\mathrm{C} / \mathrm{U}$ atom ratio in the feed was varied between 1.4 and 3.2 , the average particle size of the feed between 58 and $107 \mu \mathrm{m}$, and the solid feed rate between 0.06 and $0.9 \mathrm{~kg} / \mathrm{hr}$.

The results of this exploratory study indicate that the method might be suitable for continuous large-scale production, under critically-safe conditions, of (U,Pu)C fuel for fast breeder reactors. 


\section{SUMMARY}

The use of an induction plasma torch reactor for converting ( $\mathrm{U}, \mathrm{Pu}) \mathrm{O}_{2}$ to reactor-grade carbide spheres in high yield was explored. A $25-\mathrm{kW}$ $(4-\mathrm{MHz})$ induction plasma torch was used to convert $\mathrm{UO}_{2}$ and carbon to $\mathrm{UC}$ under various operating conditions, to examine the effects of variables on product characteristics, and to provide a basis for process evaluation. Although the experimental work was devoted to the conversion of uranium dioxide-graphite powder agglomerates to uranium monocarbide, the process is expected to be applicable to the production of $(\mathrm{U}, \mathrm{Pu}) \mathrm{C}$ in equipment installed in an alpha-tight enclosure.

The method involves making composite particles of uranium dioxide and graphite and reacting the composite particles by passing them through and cocurrently with the tail flame (pointed downward) of hydrogen-argon plasma in a 1.5-in.-ID quartz tube. Back reaction is prevented by rapid quenching of the products and by rapid separation of the gas eous product from the solid. The product, in the form of small, free-flowing spheres of carbide, is collected along with unreacted oxide-graphite agglomerates in a product receiver at the bottom of the reactor. The CO reaction product leaves the reaction chamber with the inert plasma gas.

About $20 \%$ of the particles in the product were shiny (with metallic luster) black spheres of 25-50 $\mu \mathrm{m}$. The shapes of the remainder of the particles were similar to those of the feed particles, except for some rounding off of sharp corners. The average particle size for the product was lower than that for the feed because of (1) reaction and spheroidization in the formation of the carbide spheres, (2) densification accompanying sintering of the particles, and (3) breakage of particles due to rapid evolution of the gaseous product (CO).

Between 74 and $82 \%$ of the carbon in the feed agglomerates was converted to gaseous and solid products ( $C O, U C$, and alpha- $-U_{2}$ ) in a single pass through the torch in runs with argon in the reaction chamber. These values for the carbon utilization are satisfactory for the $25-\mathrm{kW}$ induction plasma torch used. Although reaction of the graphite was incomplete in these runs, the oxide could probably be completely converted to carbide by passing the solid product from a torch through a second torch or, if only one torch was available, by recycling the solid product.

The carbon utilization was almost constant, although the solid feed conditions were varied--i.e., the solid feed rate was varied between 0.06 and $0.9 \mathrm{~kg} / \mathrm{hr}$, the average particle size between 58 and $107 \mu \mathrm{m}$, and the $\mathrm{C} / \mathrm{U}$ atom ratio in the feed between 1.4 and 3.2. Similarly, in a preliminary series of runs with granular alumina, the percentage of particles converted to spheres was almost constant, although the powder feed rate was varied between 0.6 and $1.2 \mathrm{~kg} / \mathrm{hr}$. Apparently, the upper limit for the solid feed 
rate (where the solids start cooling the plasma flame) has not been reached in the current runs and feed rates much higher than those tested may be practical. Assuming that the potentialities for higher solid feed rates and more efficient operation achieved through the use of metal-walled plasma containment tube compensate for the number of passes required for complete conversion, carbide production rates of at least $0.12 \mathrm{lb} / \mathrm{kWh}$ may be expected.

In the conversion of agglomerates to product, carbon and oxygen concentrations decreased in the same proportion; $i_{.} e_{0}$, the value of the ratio, decrease in g-atoms of carbon per g-atom of uranium/decrease in g-atoms of oxygen per g-atom of uranium, was $\sim 1.0$; this indicates that the gaseous product of the $\mathrm{UO}_{2}-$ graphite reaction in an argon-3.2 vol \% hydrogen plasma flame is CO. X-ray diffraction analys is of the solid-product samples indicated that uranium monocarbide and alpha-uranium dicarbide were present along with unreacted uranium dioxide. The concentration of dicarbide might be lowered to the desired level by a purification step, such as reduction in a hydrogen atmosphere or reaction with uranium dioxide, to form uranium monocarbide.

The current exploratory study indicates that the induction plasma torch method is worthy of further consideration for development to a fullscale facility that is critically safe for continuous conversion of $(\mathrm{U}, \mathrm{Pu}) \mathrm{O}_{2}$ to carbide spheres. However, the performance of equipment components during the 38 runs with the $25-\mathrm{kW}$ induction plasma torch indicated that the designs of the plasma containment tube, the solids feed orifices, the solids guide tube, and other components would have to be improved for further development or scale-up of the conversion process.

\section{INTRODUCTION}

Conversion of fast-breeder-reactor oxide to reactor-grade carbide fuel in an induction plasma torch reactor has the potential for converting the oxide-graphite particles to carbide spheres in critically safe equipment that can be continuously operated. Criticality safety and continuous operation are desirable features for commercial production of nuclear fuels. However, the feasibility of the production of carbide spheres from oxide in an induction plasma torch reactor has not been reported in the literature.

The objective of the current study was to determine the feasibility of the production of the carbide spheres using an induction plasma torch reactor. The experimental work was limited to the conversion of uranium dioxide and graphite powder agglomerates to uranium monocarbide, but the process is expected to be applicable to the production of ( $U, P u) C$ (which would have to be done in equipment installed in an alpha-tight enclosure). The objective of the experimental work was to determine the operating conditions required to produce high yields of reactor-grade uranium monocarbide. 
A schematic flowsheet for the conversion of (U,Pu) $\mathrm{O}_{2}$ to $(\mathrm{U}, \mathrm{Pu}) \mathrm{C}$ spheres using an induction plasma torch reactor is shown in Fig. 1. The method includes (1) preparing 100- $\mu \mathrm{m}$ composite particles of (U, $\mathrm{Pu}) \mathrm{O}_{2}$ and carbon, (2) reacting the composites by passing them through and cocurrently with the plasma flame of an inductively coupled plasma torch pointed downward, (3) separating (U,Pu)C product spheres from the nonspheres and unreacted particles, (4) separating the CO reaction product from the plasma gas, and (5) recycling the unreacted particles, nonspheres, and the plasma gas to the reactor.

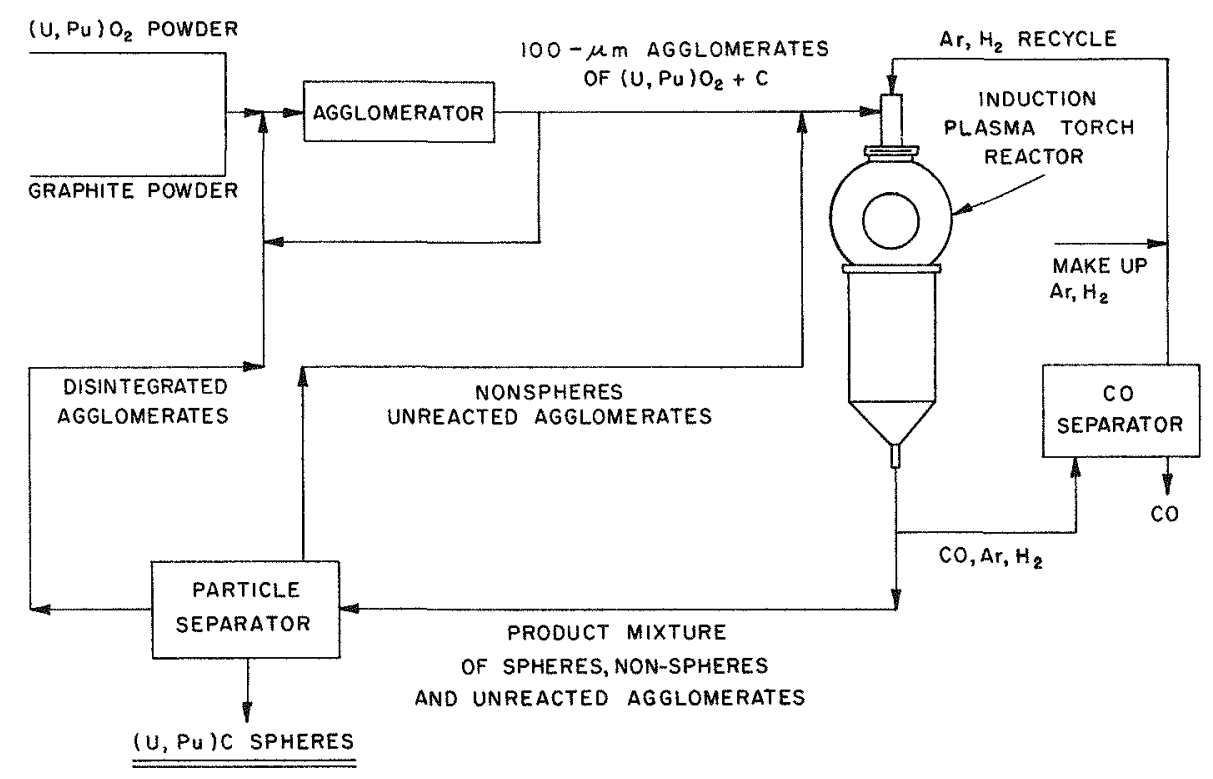

Fig. 1. Conversion of $(\mathrm{U}, \mathrm{Pu}) \mathrm{O}_{2}$ to Carbide Spheres in an Induction Plasma Torch Reactor

Of the methods described in the literature for preparing composite particles of ( $\mathrm{U}, \mathrm{Pu}) \mathrm{O}_{2}$ and carbon, the better-developed on $\mathrm{e}^{1,2}$ consists of mixing 1 - to $2-\mu \mathrm{m}$ particles of $(\mathrm{U}, \mathrm{Pu}) \mathrm{O}_{2}$ and graphite in a $\mathrm{V}$-blender together with a small amount of binder such as polyvinyl alcohol. After the dry powder is mixed, a small amount of water is added and mixing is continued until the agglomerates form and finally reach the desired size. The agglomerates are dried at $50^{\circ} \mathrm{C}$. Other ways of preparing intimate mixtures of $\left(\mathrm{U}, \mathrm{Pu} \mathrm{O}_{2}\right.$ and carbon are from a nitrate solution containing sugar ${ }^{3,4}$ or perhaps from a mixture of the oxides and sugar solution. Any of these methods can be adapted to the preparation of the feed required for the plasma torch method.

In the induction plasma torch reactor, the composite particles of $(\mathrm{U}, \mathrm{Pu})_{2}$ and graphite are passed through and cocurrently with the plasma flame at high velocities in the form of a tubular column. The residence times of particles in the flame are of the order of a few milliseconds. Particle heating occurs by several mechanisms, including thermal conduction through the boundary layer surrounding the particle, radiation, electron 
bombardment, and electron recombination on the particle surface. The extent of conversion of the oxide to the carbide depends on the time/ temperature history of the particles. Back reaction is prevented by rapid quenching of the products and rapid separation of the gaseous product from the solid.

The solid product, in the form of small, free-flowing spheres of carbide accompanied by unreacted oxide-graphite particles, is collected in a product receiver at the bottom of the reactor (although a different experimental setup might provide for continuous transport of the product to the next process step). Commercially available equipment could be used to separate high-density carbide spheres from nonspheres and low-density unreacted agglomerates. Incompletely reacted material would be recirculated to the reactor or to an agglomerator system, depending on particle size. The dense spheres of carbide would be fabricated into fuel elements.

The gaseous reaction product, CO, leaves the reaction chamber with the inert plasma gas, argon (or hydrogen-argon mixture). The carbon monoxide is separated from the plasma gas by well-known commercial methods, ${ }^{5-7}$ and the plasma gas is recycled to the torch.

\section{LITERATURE REVIEW}

Spheroidization of various powders using induction plasma torches has been reported in the literature, as well as synthesis and spheroidization of uranium carbides with dc-arc plasma jets. Work related to the expected performance of an induction plasma torch reactor for the conversion of uranium dioxide-graphite agglomerates to uranium carbide spheres is reviewed here.

\section{A. Spheroidization Studies Using Induction Plasma Torches}

An induction plasma torch ( $10 \mathrm{~kW}, 5 \mathrm{MHz}$ ) enclosed in an alpha box was used by Jones et ${ }^{2} .^{8,9}$ for producing thermally and chemically stable microspheres of plutonium dioxide. The microspheres were $10-250 \mu \mathrm{m}$ in diameter, the majority were dense, solid, crystalline particulates, and a small percentage had internal voids. The density of the product was $96 \%$ of the theoretical crystalline density.

Browne and Latta ${ }^{10}$ reported spheroidization of $\mathrm{UO}_{2}, \mathrm{ThO}_{2}$, and $\mathrm{ZrO}_{2}$ particles with a $7.5-\mathrm{kW}(5-\mathrm{MHz})$ induction plasma torch.

Hedger and Hall ${ }^{11}$ studied spheroidization of the powders of chromium, molybdenum, tantalum, tungsten, alumina, magnesia, and several compounds of uranium using a $25-\mathrm{kW}$ induction plasma torch. The studies were mainly 
confined to 100 - to $150-\mu \mathrm{m}$ particles, and powder feed rates of 0.06 to $0.3 \mathrm{~kg} / \mathrm{hr}$ were used. Yields of 50 to $70 \%$ spheroidization (in a single pass through a plasma torch) were obtained.

Tremper ${ }^{12}$ used a $10-\mathrm{kW}$ induction plasma torch for the spheroidization of ceramic powders. He found that the frequency range of $4-6 \mathrm{MHz}$ was best for spheroidization, almost entirely because in this range plasma was the most stable. For most of the work, the high-frequency power was furnished through a four-turn cylindrical coil (made of 3/16-in. copper tubing) at a frequency of $4 \mathrm{MHz}$. A solids feed nozzle that gave laminar flow of the powder provided a much higher degree of spheroidization than any other nozzle tried by him. Powder feed rate was $0.06 \mathrm{~kg} / \mathrm{hr}$. For a single pass of 43- to $61-\mu \mathrm{m}$ silica powder through the plasma torch, the powder was approximately $75 \%$ spheroidized; two passes of the powder through the torch gave about $90 \%$ spheroidization. The resulting silica spheres were all nearly $100 \%$ dense, with only a few small bubbles in them. The spheroidization of $40-\mu \mathrm{m}$ alumina upon one pass through the induction plasma torch was about $65 \%$, upon two passes $80 \%$, and upon three passes $90 \%$. About half of the alumina spheres produced had nearly theoretical density.

B. Synthesis and Spheroidization of Uranium Carbides

A dc-arc plasma jet method of making spherical actinide carbide was patented by White and O'Rourke. ${ }^{13}$ In this method, agglomerates (70 to $150 \mu \mathrm{m})$ of $\mathrm{UO}_{2}$ and carbon fed to a dc-arc plasma are entrained by the jet. The actinide carbide product flowing from the tip of the jet consists of completely reacted, spherical (50 to $125 \mu \mathrm{m}$ ) particles. A small amount of hydrogen, less than $1 \mathrm{vol} \%$, added to the inert plasma gas, acted as a promoter that helped drive to completion the reaction of the $\mathrm{UO}_{2}$ and carbon.

Gibson and Weidman ${ }^{14}$ used a consumable homogeneous anode of $\mathrm{UO}_{2}$ and carbon to produce a uranium-carbon plasma. The temperature at the tip of the anode is raised to $3700-4700^{\circ} \mathrm{C}$ in a chamber at a pressure of $0.1-5 \mathrm{~mm} \mathrm{Hg}$. The very high temperature initiates the extremely rapid reaction

$$
\mathrm{UO}_{2}(\mathrm{~s})+3 \mathrm{C}(\mathrm{s}) \rightarrow \mathrm{UC}(\mathrm{s})+2 \mathrm{CO}(\mathrm{g})
$$

and the solid product formed quickly melts. The molten uranium carbide on the anode face becomes a zone that is heated to the boiling point of the system. The liquid product that drips from the reaction zone is completely outgassed of lower-boiling-point impurities, and a high-density, high-purity solid product is collected. The density of uranium carbide spheres produced in this manner was 97 to $99+\%$ of theoretical, the purity was $99.95 \%$, and the diameters were 44 to $6000 \mu \mathrm{m}$. The production rate was about $0.18 \mathrm{lb}$ of UC per $\mathrm{kWh}$ of dc input. 
Synthesis of uranium carbide by the gas-phase reaction of $\mathrm{UF}_{6}$ with methane and hydrogen was investigated by Helton, ${ }^{15}$ who used a dc-arc plasma jet. Some uranium carbide was formed when finely divided SiC was premixed with the gaseous mixture and then introduced into the plasma jet. Analysis of the product by $\mathrm{X}$-ray diffraction showed that small quantities of uranium dicarbide and uranium monocarbide were present. However, yields were never greater than $1 \%$.

Synthesis of uranium carbide from a mixture of uranium tetrafluoride and silicon carbide was explored by Helton, ${ }^{15}$ who used an induction plasma torch. A mixture of powdered uranium tetrafluoride and silicon carbide was fed to the torch at a rate of $0.06-0.12 \mathrm{~kg} / \mathrm{hr}$. The solids (product) obtained from the reaction were analyzed by $X$-ray diffraction. A trace of uranium monocarbide was present. Quantitative yields were never greater than $\sim 1 \%$.

Jets of plasma generated by passing a gas through a dc arc were extensively used in early investigations on spheroidization of carbide particles. Sturge and $S_{\text {myth }}{ }^{16,17}$ investigated the spheroidization of $(\mathrm{U}, \mathrm{Th}) \mathrm{C}_{2}$ with a $20-\mathrm{kW}$ dc-arc argon plasma jet. For $500-\mu \mathrm{m}$ agglomerates fed at $0.2 \mathrm{~kg} / \mathrm{hr}$, spheroidization was better than $99 \%$. Throughputs greater than $0.2 \mathrm{~kg} / \mathrm{hr}$ tended to produce ovoids. For 250 - to $353-\mu \mathrm{m}$ agglomerates of $\mathrm{UZ}$ rC with $24-\mathrm{kW}$ input dc, spheroidization rates of $0.2 \mathrm{~kg} / \mathrm{hr}$ were reported by Jacques and Sturge. ${ }^{18}$ Bildstein ${ }^{19}$ reported an investigation using a dcarc plasma jet in which $(\mathrm{U}, \mathrm{Th}) \mathrm{C}_{2}$ and $\mathrm{UC}_{2}$ particles up to $500 \mu \mathrm{m}$, and UZrC particles up to $350 \mu \mathrm{m}$, were spheroidized in one pass to the extent of $98 \%$ 。

C. Expected Performance of Plasma Torch

From the above literature review, factors affecting the conversion of uranium dioxide to uranium carbide were inferred assuming that (1) the yields of spheroidized particles described above represent the quantity of heat transferred from a plasma to particles, (2) the reaction kinetics do not limit the extent of reaction, and hence (3) the yields indicate the extent of endothermic reaction to be expected with an induction plasma torch. Conversion of uranium dioxide to uranium carbide was expected to be affected by operating conditions in the following manner:

1. With powder feed rates of $0.06-0.3 \mathrm{~kg} / \mathrm{hr}$ to a $25-\mathrm{kW}$ induction plasma torch, product yields should be 50-70\% in a single pass of $100-\mu \mathrm{m}$ particles, since in other investigations spheroidization yields were in this range for these operating conditions.

2. The product yield should increase with an increased number of passes through the plasma torch.

3. Yield should increase if a diatomic gas such as hydrogen is added to the plasma gas. 
4. Yields should be higher with a solids feed nozzle that gives laminar flow of the powder than with other types of nozzles.

5. Product spheres should have near-theoretical density.

6. Torch operation in an alpha-tight enclosure should be feasible.

\section{EQUIPMENT AND OPERATING PROCEDURE}

A. Equipment

The equipment for study of the conversion of uranium dioxide to uranium carbide consists of an induction plasma torch, an $\mathrm{rf}$ power supply, a water-cooled reaction chamber, a product receiver assembly, a powder feeder, a gas supply system, and associated instrumentation. A schematic diagram of the plasma-torch installation is shown in Fig. 2 .

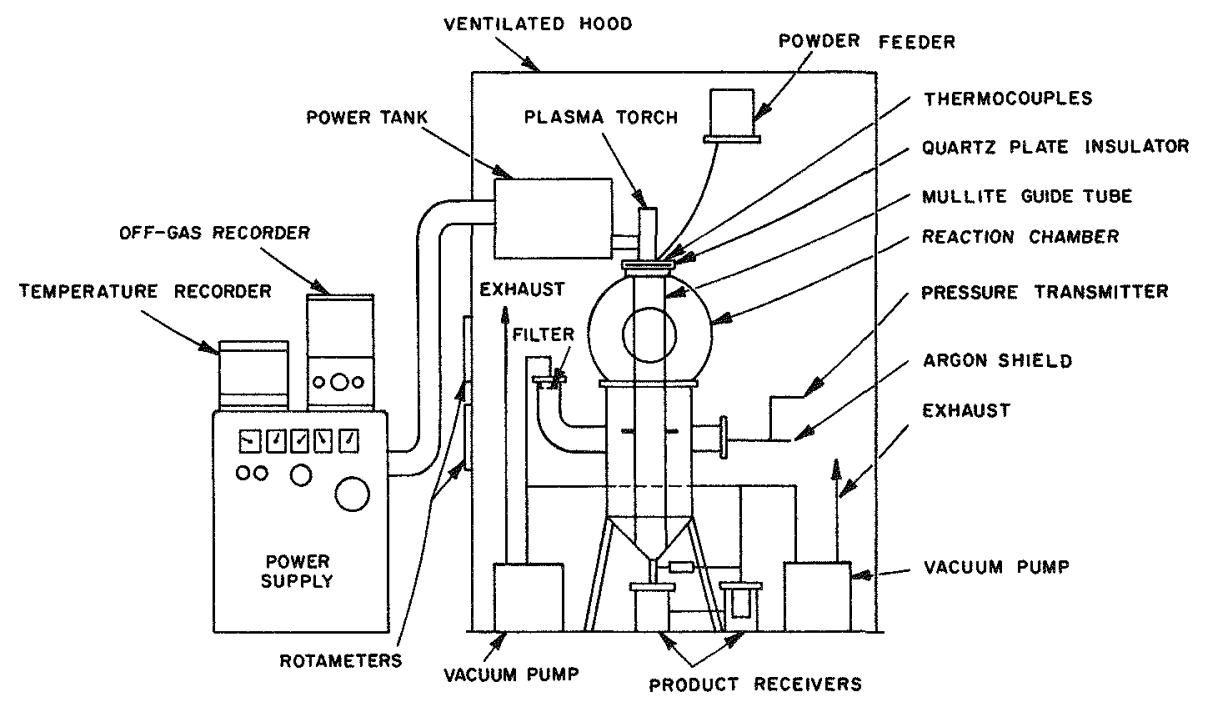

Fig. 2. Installation of Plasma Torch for Studying Conversion of Uranium Dioxide to Uranium Carbide

The induction plasma torch is held on a quartz plate insulator on the top flange of the water-cooled reaction chamber (see Fig. 3). The plasma torch (TAFA* Mode1 56) consists of a 1.5-in.-ID quartz tube surrounded by an induction coil immersed in cooling water. About 3 in. of the tube length is covered by the induction coil; a plastic casing enclosing the tube and coils is supplied with cooling water by passages that also carry the rf power leads. The torch is designed so that plasma generation occurs only within the water-cooled quartz tube. The rf coil is energized by a Lepel Model T-25 vacuum-tube high-frequency generator rated for $25 \mathrm{~kW}$.**

\footnotetext{
* TAFA Division, Humphreys Corporation, Concord, N. H.

** Lepe1 High Frequency Laboratories, Inc., Queens, N. Y.
} 
The power is delivered to the torch at a frequency of $4 \mathrm{MHz}$. Additional details on the design of the torch may be found in the manufacturer's literature..$^{20}$ The basic principles of $\mathrm{rf}$ plasma formation are discussed in detail by Baddour and Timmins. ${ }^{21}$

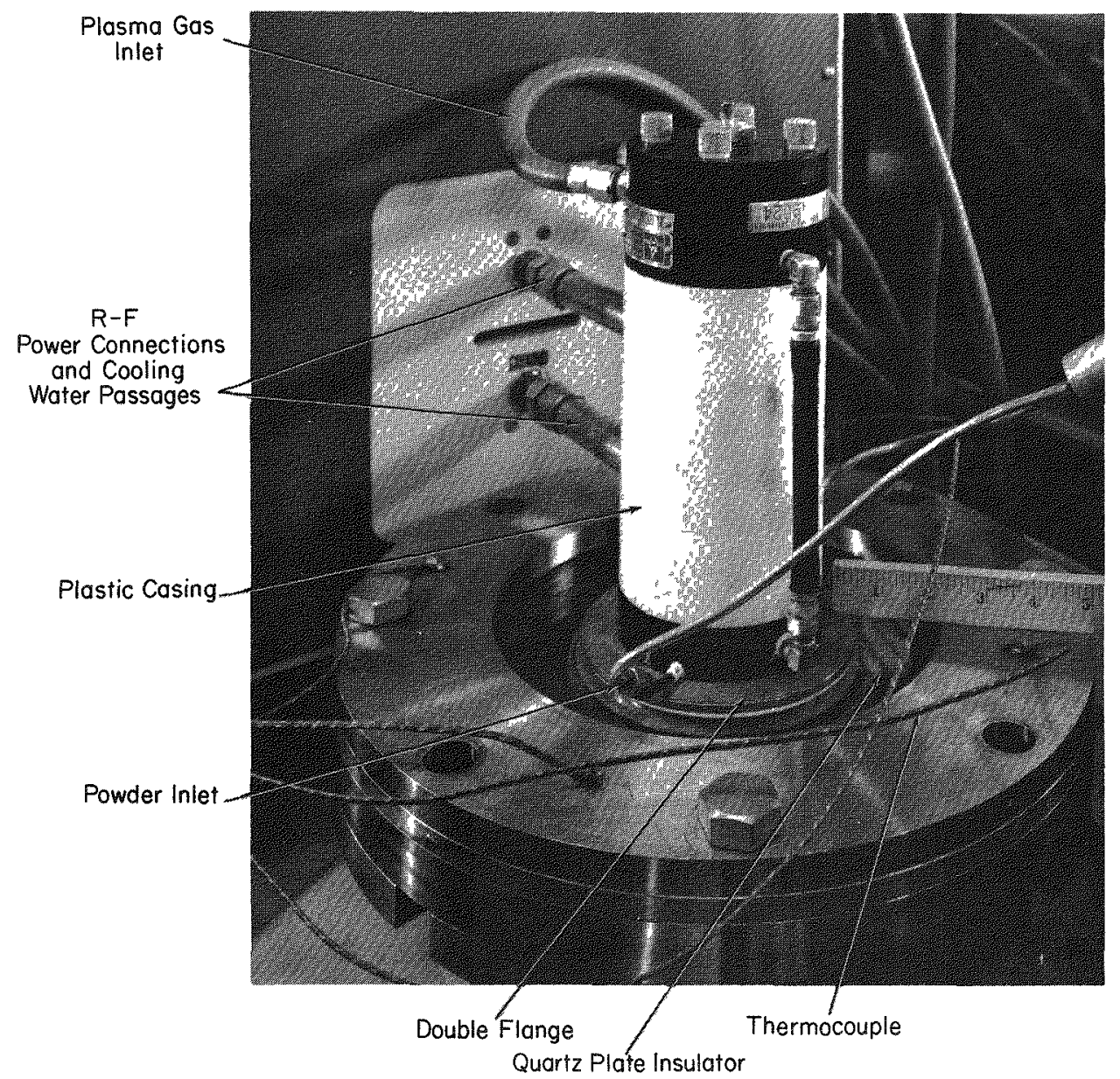

Fig. 3. Plasma Torch Mounted on Top Flange of Reaction Chamber. ANL Neg. No. 308-2115.

The plasma gas, argon (or hydrogen-argon mixture), is fed in a controlled pattern to the quartz tube through inlets located in the gas injector retainer at the top of the tube. The gas may be introduced radially, tangentially, or axially into the tube to establish the desired flow pattern. Argon and hydrogen are supplied from a cylinder manifold at the desired flow rates. Controls prevent startup of the torch without adequate flow of the gases. The flow rates are metered with rotameters.

The agglomerated uranium dioxide-graphite powder is fed to the plasma torch by a Model 104 power feeder supplied by TAFA. The powder feeder operates on a vibrating feed principle. Up to $0.5 \mathrm{~kg}$ of powder is loaded into a bowl, and the vibration intensity of the bowl is controlled with a rheostat. The powder drops into a collecting tube and is transported by 
the carrier gas (argon) to the plasma torch. The agglomerates are fed into the flame downstream from the plasma-generation zone. The powder inlet is located in the nozzle at the bottom of the plasma containment (quartz) tube.

A brass double flange holds the torch and the quartz plate insulator that supports the torch. The maximum permissible operating temperature for the brass double flange is $400^{\circ} \mathrm{C}$. The quartz plate* $(0.75 \mathrm{in}$. thick with a $4.625 \mathrm{in.}$. D and a $10 \mathrm{in.} \mathrm{OD),} \mathrm{in} \mathrm{addition} \mathrm{to} \mathrm{supporting} \mathrm{the} \mathrm{torch,} \mathrm{serves}$ as a thermal and electrical insulator between the plasma torch and the top flange of the water-cooled reaction chamber. Four thermocouples are affixed on the top flange. Temperature records obtained with the four thermocouples are used as an index of thermal equilibrium attained in the reaction chamber.

The reaction chamber is a 28 -in.-ID spherical section, mounted on the top of an 18-in.-ID, 40-in.-deep cylindroconical section (see Fig. 2). The entire reaction chamber is made of Type 304 stainless steel. The two sections of the reaction chamber are double-walled with cooling water flowing through the annulus between the two walls. The cooling-water flow rates for the two sections are controlled and metered independently of each other.

A mullite guide tube (5.6 in. ID, 6.1 in. OD, 27 in. long) is centrally located below the torch to contain the tail flame and to direct the particles into the product receiver. The chamber pressure is recorded by a pressure transmitter and recorder assembly. The induction plasma torch reactor assembly is shown in Fig, 4. The reactor assembly is located inside a ventilated hood. The ventilation-air flow rate through the hood is about $1500 \mathrm{cfm}$.

The product receiver assembly (see Fig. 5) consists of a primary receiver (4 in. ID and $7.5 \mathrm{in.} \mathrm{high)} \mathrm{for} \mathrm{the} \mathrm{product,} \mathrm{a} \mathrm{secondary} \mathrm{receiver}$ containing a bayonet-type sintered-nickel filter ( 1.75 in. wide, 6 in. long), and a bypass line that contains a nickel-wool filter. This type of product receiver assembly is designed to separate the solids from the gas stream while steady flow patterns and pressure are maintained inside the plasma torch. The large particles (the major fraction of the solids) are separated from the gas stream in the primary receiver. The fine particles entrained in the gas stream are retained on the sintered-nickel filter in the secondary receiver. If the pressure in the reaction chamber tends to build up rapidly, the bypass line containing the nickel-wool filter can be opened to exhaust the gases and relieve the pressure. The off-gas (containing the gaseous reaction product, $\mathrm{CO}$ ) is exhausted from the product receiver assembly by two Duo-Seal vacuum pumps (free-air pumping rates of 800 and $300 \mathrm{ft}^{3} / \mathrm{hr}$ ) operating in parallel.

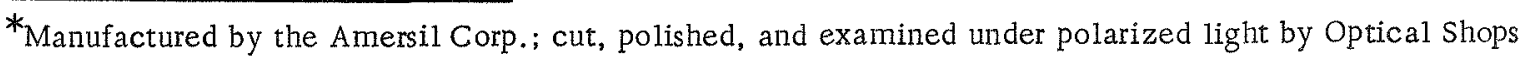
(Central Shops, ANL). 


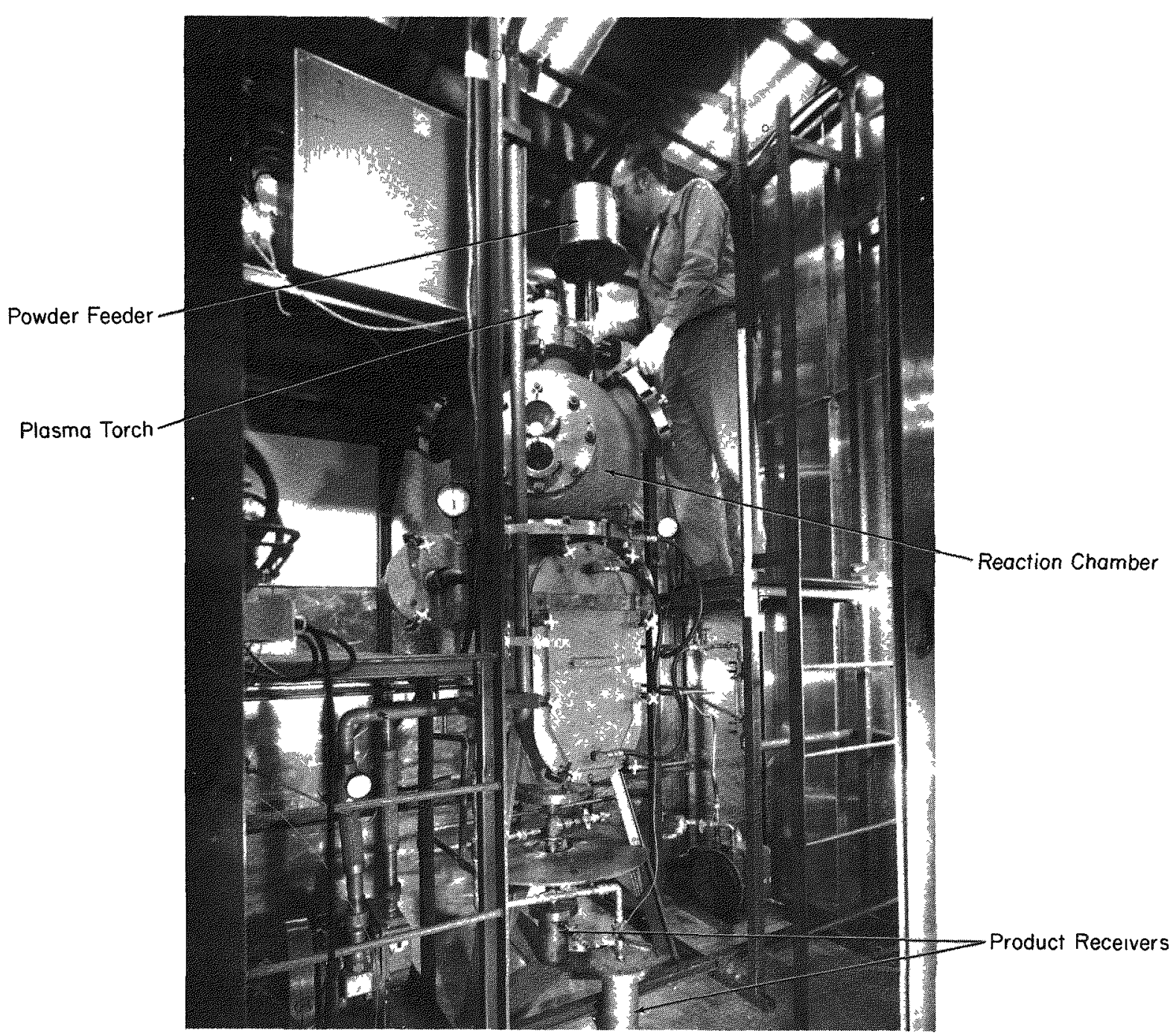

Fig. 4. Induction Plasma Torch Reactor. ANL Neg. No. 308-2114.

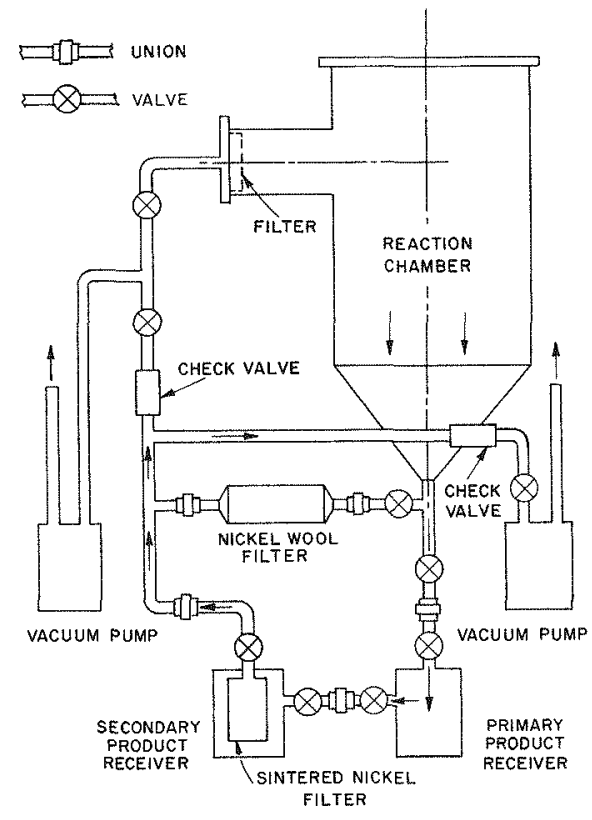

Fig. 5

Product Receiver Assembly 
B. Operating Procedure

The operating procedure includes (1) making composite particles of uranium dioxide and graphite, (2) passing them through and cocurrently with the plasma flame of the induction plasma torch, (3) collecting the carbide product in a receiver at the bottom of the reactor, and (4) sampling the solid product for subsequent analysis to determine the extent of conversion of the oxide to carbide.

$\mathrm{UO}_{2}$ powder* $(0.5-1 \mu \mathrm{m})$, graphite powder** $(\sim 3 \mu \mathrm{m})$, and a small amount of polyvinyl alcohol binder $\mathrm{r}^{\dagger}$ are dry-mixed in a Patterson-Kelly twin-shell blender for at least $16 \mathrm{hr}$. Distilled water is added incrementally to the tumbling mixture in the blender until small agglomerates are formed. Tumbling is continued until the size of the agglomerates increases to the desired value. The agglomerates are dried at $50^{\circ} \mathrm{C}$ for at least $16 \mathrm{hr}$ and separated by sieving. The resulting particles $(107 \mu \mathrm{m})$ have a bulk density of about $2.8 \mathrm{~g} / \mathrm{ml}$ and a particle density of about $4.6 \mathrm{~g} / \mathrm{ml}$. The method of preparing the composite particles of uranium dioxide and graphite is adapted from that reported by Strausberg. ${ }^{1}$ The polyvinyl alcohol is reported by Strausberg to contribute $10 \%$ of its initial weight as carbon, which is available as a reactant; the remainder of this compound is volatilized during the reaction.

The powder feeder is loaded with a specified quantity (up to $0.5 \mathrm{~kg}$ ) of the $\mathrm{UO}_{2}$-carbon agglomerates of specified stoichiometry and size. To displace the ambient air completely from the powder feeder, the reaction chamber, and the product receiver assembly (see Figs. 4 and 5), they are evacuated (to $70 \mu \mathrm{m} \mathrm{Hg}$ ) and filled with argon, cyclically six times.

The desired flow rates for plasma gas and cooling water (to the torch and to the reaction chamber) are established. The rf coil is energized and the input current is increased incrementally until the torch is lit at about $8 \mathrm{~kW}$. The gas flow rates and the input current are then increased to predetermined values. The temperature of the top flange of the water-cooled reaction chamber gradually increases, starting when the torch is lighted, and reaches a steady value (about $85^{\circ} \mathrm{C}$ ) in $1 \mathrm{hr}$, when the apparatus has reached thermal and electrical equilibrium.

After the induction plasma torch reactor attains electrical and thermal equilibrium, powder feeding is started and continued for the predetermined feed period. Then the torch is turned off by reducing the input current to zero, and the product receivers are isolated. After power is cut off, gas and water flows are continued for a few hours to cool the

\footnotetext{
* Supplied by Nuclear Fuel Services, Erwyn, Tennessee.

** Supplied by National Carbon Company, New York, New York.

†supplied by J. T. Baker \& Co., Phillipsburg, N. J.
} 
induction plasma torch reactor. The procedures outlined in the TAFA instruction manual for preventing possible hazards are followed while the plasma torch is being operated.

The isolated product receivers are transferred to a glovebox having a helium atmosphere to avoid exposure of the solid product to oxygen in the ambient air and to prevent possible oxidation. The product is sampled for identification of its components by $\mathrm{X}$-ray diffraction analysis and for the determination of free carbon, total carbon, and oxygen contents.

\section{RESULTS AND DISCUSSION}

Thirty-eight runs were made in the current exploratory study on the conversion of uranium dioxide to uranium carbide in an induction plasma torch reactor. The initial 21 spheroidization runs (discussed in Appendix A) were made to determine the operating characteristics of the plasma torch. Granular alumina was used as the solid feed in the initial 21 runs because of ease in reactor operation with alumina feed. Agglomerates of $\mathrm{UO}_{2}$ and graphite powder were used as the solid feed in the remaining 17 runs. The detailed operating conditions and data for all 38 runs are tabulated in Appendixes $\mathrm{A}$ and $\mathrm{B}$.

The ranges of operating conditions tested for the conversion of uranium dioxide-graphite agglomerates to uranium carbide are given in Table I. These ranges of operating conditions were selected based on the results of the initial runs. Formation of carbide spheres, utilization of carbon in chemical reactions, production rates of carbides, identification of gaseous and solid products, and process scale-up considerations are discussed below.

TABLE I. Ranges of Conditions Tested for Conversion of Uranium Dioxide-Graphite Agglomerates to Uranium Carbide in Induction Plasma Torch Reactor

\begin{tabular}{lcc}
\hline & $\begin{array}{c}\text { Low } \\
\text { Value }\end{array}$ & $\begin{array}{c}\text { High } \\
\text { Value }\end{array}$ \\
\hline C/U atom ratio in the feed & 1.4 & 3.2 \\
Particle size of the feed agglomerates, $\mu \mathrm{m}$ & 53 & 125 \\
Feed rate, $\mathrm{kg} / \mathrm{hr}$ & 0.06 & 1.2 \\
Feed duration, min & 2 & 60 \\
Power input to the oscillator, kW & 15.2 & 20.0 \\
Plasma gas flow rate, scfh & 131 & 158 \\
Concentration of hydrogen in plasma gas & 0 & 6.0 \\
\hline
\end{tabular}


A. Formation of Carbide Spheres

Some spherical, shiny (with metallic luster) black particles of 25-50 $\mu \mathrm{m}$ were observed in product samples. Typical uranium carbide spheres produced in the induction plasma torch reactor are shown in Fig. 6. These spheres apparently are very dense.

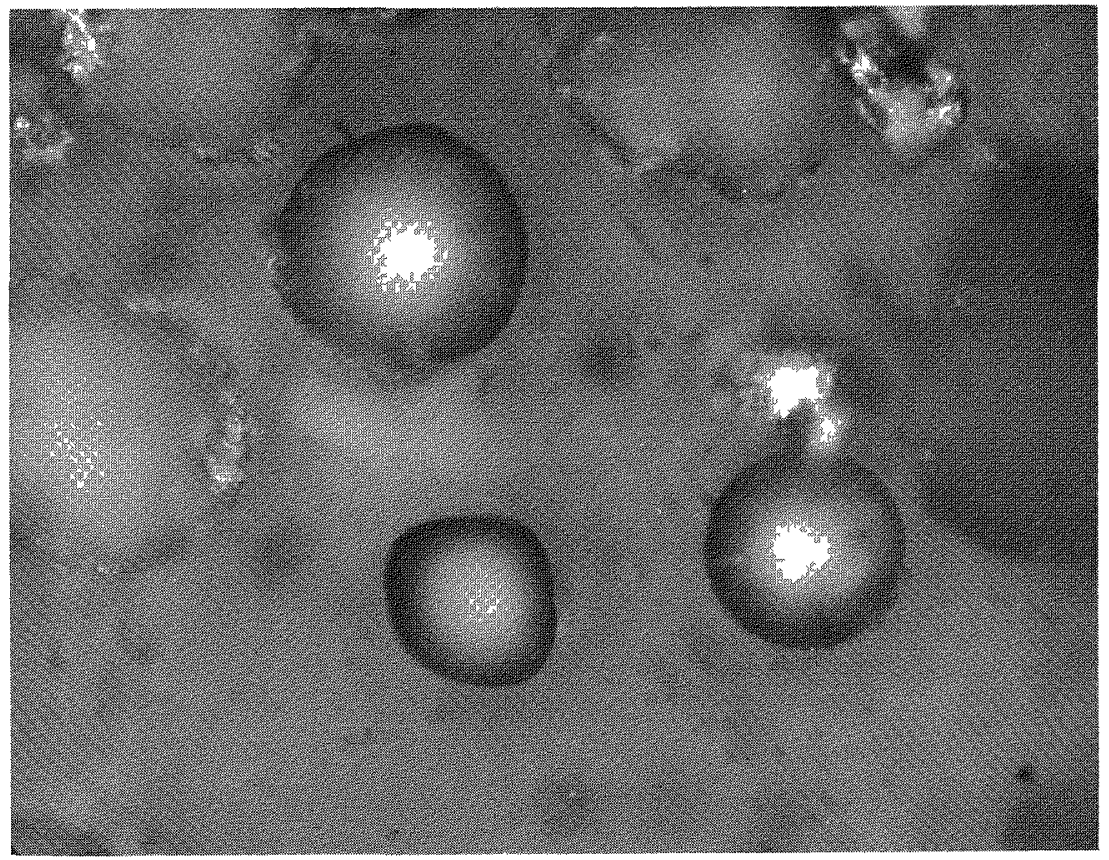

Fig. 6. Typical Uranium Carbide Spheres Produced in Induction Plasma Torch Reactor. Mag. 500X.

About $20 \%$ of the product particles were spheres. The remainder of the particles had shapes similar to those in the feed, with some rounding off of sharp corners. Figure 7 shows the uranium dioxide and graphite agglomerate feed powder and the carbide product of Run 18. The product is typical of that obtained in one pass of the agglomerates through the induction plasma torch. Figure 6 is a magnified view of the spheres at the center of Fig. $7 \mathrm{~b}$.

The average particle size was lower for the product than for the feed because (1) reaction and spheroidization had occurred, (2) densification accompanied sintering of the particles, and (3) breakage accompanied the rapid evolution of gaseous product (CO). Methods are commercially available for separating spheres from nonspheres. Hence, in the present exploratory study, no attempt was made to demonstrate the feasibility of separating carbide spheres from nonspheres in the product.

The operating conditions and the characteristics of the induction plasma torch system influence the degree of spheroidization and the percentage of carbide spheres in the solid product. Determination of the effects of these factors on the yield of carbide spheres was beyond the scope of the present study. 


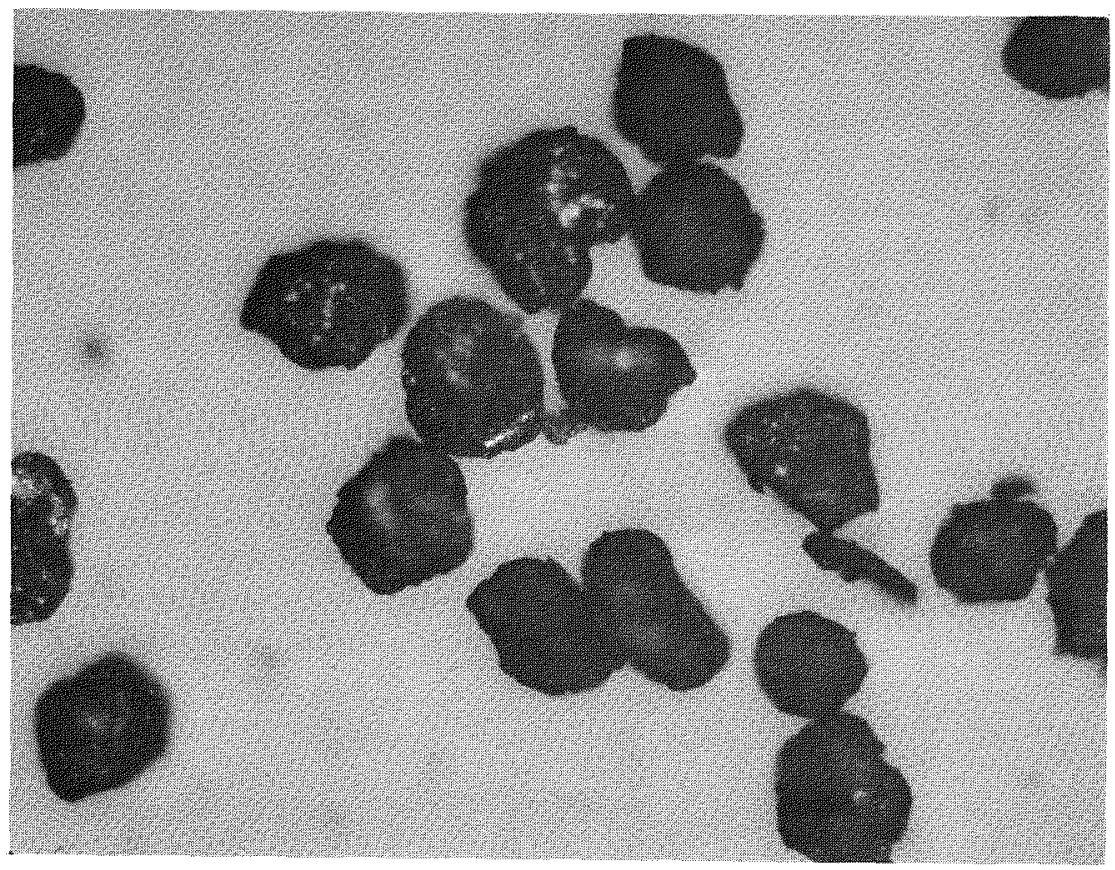

a. Uranium Dioxide and Graphite Agglomerates. Mag. 200X.

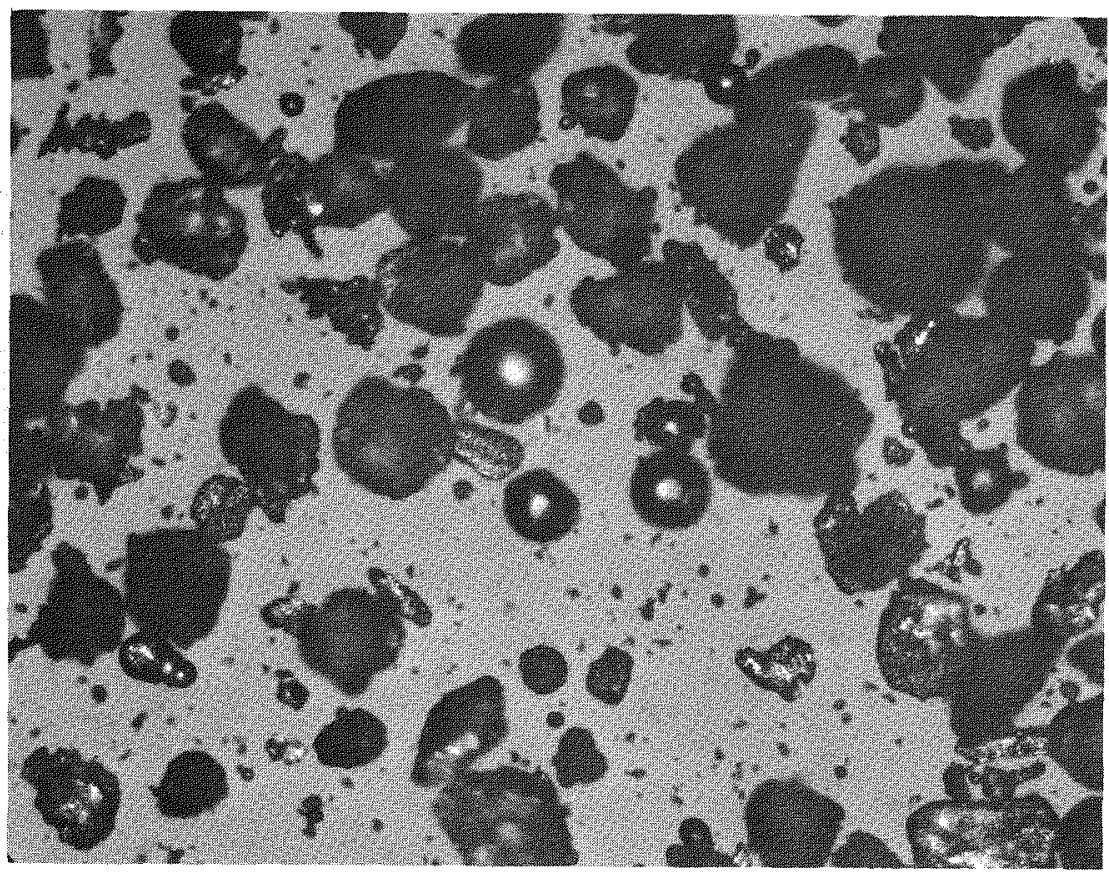

b. Carbide Product after One Pass of the Agglomerates through the Induction Plasma Torch. Mag. 200X.

Fig. 7. Typical Uranium Dioxide-Graphite Agglomerates and Carbide Product (Run 18)

B. Utilization of Carbon in Chemical Reaction and Production Rates of Carbide

Composite particles of $\mathrm{UO}_{2}$ and carbon at room temperature are fed to the plasma flame, which is pointed downward inside the induction plasma 
torch reactor. As the particles pass through the various temperature zones of the plasma flame, particle heating occurs by several mechanisms, including thermal conduction through the boundary layer surrounding a particle, radiation, electron bombardment, and atom recombination on the particle surface. The particles falling through the hot central zone of the flame reach the highest temperatures, greater than $2500^{\circ} \mathrm{C}$ (the melting point of UC); those falling through the cooler peripheral zone of the flame reach lower temperatures. The average temperature of the particles increases rapidly, then falls to room temperature as the particles are quenched and collected in the product receiver.

The reactions of $\mathrm{UO}_{2}$ and carbon ${ }^{22,23}$ begin at $1150-1200^{\circ} \mathrm{C}$, and the reaction rates are dependent on the temperatures attained by the composite particles. The percentage of carbon utilized in the reactions is the measure of performance of the plasma torch, just as the percentage of particles melted is the performance criterion in investigations of spheroidization of granular materials (see Section III.A.). The percentage of carbon in the feed converted to gaseous and solid products is determined from the total carbon in the feed agglomerates and from the total carbon and free carbon in the solid product thus:

Utilization of carbon $=\frac{\left\{\begin{array}{l}g \text { atoms of } C \text { per g atom of } U \\ \text { in the feed agglomerates }\end{array}\right\}-\left\{\begin{array}{l}\text { Unreacted } g \text { atoms of } C \text { per } g \\ \text { atom of } U \text { in the solid product }\end{array}\right\}}{\left\{\begin{array}{l}g \text { atom of C per g atom of } U \\ \text { in the feed agglomerates }\end{array}\right\}}$.

The utilization of carbon was $74-82 \%$ (see Table II). These data suggest that at least $74-82 \%$ of the particles, which were at room temperature when fed into the plasma flame, might have reached temperatures above $1200^{\circ} \mathrm{C}$.

TABLE II. Utilization of Carbon in Chemical Reactions

Plasma gas flow rate: $132 \mathrm{scfh}$

Power input to oscillator: $15.9 \mathrm{~kW}$

Powder feed: Tail flame of the plasma torch

\begin{tabular}{|c|c|c|c|c|c|c|c|c|}
\hline Run & \multicolumn{3}{|c|}{$\begin{array}{l}\text { Composition of } \\
\text { Uranium Dioxide- } \\
\text { Carbon Agglomerate }\end{array}$} & $\begin{array}{l}\text { C/U Atom } \\
\text { Ratio in } \\
\text { the Feed }\end{array}$ & $\begin{array}{c}\text { Nominal } \\
\text { Feed Rate } \\
\text { of Agglomerates, } \\
\mathrm{kg} / \mathrm{hr}\end{array}$ & $\begin{array}{l}\text { Duration of } \\
\text { Feeding, min }\end{array}$ & $\begin{array}{c}\text { Average } \\
\text { Particle } \\
\text { Size of } \\
\text { Agglomerates, } \\
\mu \mathrm{m}\end{array}$ & $\begin{array}{l}\text { Utilization } \\
\text { of Carbon, } \\
\% \text { carbon } \\
\text { in feed }\end{array}$ \\
\hline 15 & 79.2 & 8.7 & 12.1 & 2.2 & 0.9 & 10 & 107 & 82 \\
\hline 16 & 79.2 & 8.7 & 12.1 & 2.2 & 0.9 & 10 & 107 & 82 \\
\hline
\end{tabular}

The values of carbon utilization achieved in the current work are slightly higher than the percentages of particles melted (50-70\%) by making a single pass of granular materials through a $25-\mathrm{kW}$ induction plasma torch at other sites (see Section III.A.). Results for the runs with agglomerates may also be compared with those from the initial runs of the current 
work, in which granular alumina was fed into the plasma zone and $89 \%$ of the alumina granules melted under operating conditions somewhat similar to conditions for runs with agglomerates. The carbon-containing agglomerates have less favorable emissivity and thermal conductivity compared to alumina granules, and the carbon-containing agglomerates are more difficult to heat than alumina granules. Hence, the value of utilization of carbon reported above appears to be the maximum limit for this system with particle injection into the tail flame of the plasma torch. These results indicate that to attain complete conversion of the oxide to the carbide, either the solid product from the torch has to be passed through a second torch or (if only one torch is available) the product has to be recycled.

The carbon utilization was almost constant (within experimental error) although the solid feed conditions were varied--i.e., the solid feed rate was varied between 0.06 and $0.9 \mathrm{~kg} / \mathrm{hr}$, the average particle size between 58 and $107 \mu \mathrm{m}$, and the $\mathrm{C} / \mathrm{U}$ atom ratio in the feed between 1.4 and 3.2 (see Table II). Similarly, in the initial series of runs with alumina, the percentage of particles converted to spheres was almost constant al though the powder feed rate was varied between 0.6 and $1.2 \mathrm{~kg} / \mathrm{hr}$. Apparently, feed rates for uranium dioxide-graphite agglomerates higher than $0.9 \mathrm{~kg} / \mathrm{hr}$ or $0.12 \mathrm{lb} / \mathrm{kWh}$ would not reduce utilization of the reactants, and the upper limit for feed rates (where the solids start to cool the plasma flame) was not reached in the current runs.

Operating conditions for the current runs included low-enthalpy argon-3.2 vol \% hydrogen plasma flame, at low power inputs ( $15.9 \mathrm{~kW})$ to the oscillator. To operate the torch with high-enthalpy plasma flame, it may be necessary to install a plasma containment tube protected by a metal shield in place of the quartz tube. With this modification, higher overall carbide production rates may be obtained than with the present equipment. Another modification suggested is an improved design of solids-injection orifices to effect higher solids introduction rates than in the current study, which may result in higher carbide production rates. Performance of equipment components is discussed in Appendix C.

On the basis of current results, carbide production rates of at least $0.12 \mathrm{lb} / \mathrm{kWh}$ can be expected, if it is assumed that the potential for higher feed rates and more efficient operation related to the use of a metal-walled plasma containment tube is offset by the need for several passes for complete conversion. This production rate can be compared with that $(0.18 \mathrm{lb}$ of UC per $\mathrm{kWh}$ ) achieved by Gibson and Weidman, ${ }^{14}$ who used an anode of $\mathrm{UO}_{2}$ and carbon forming a dc-arc plasma.

\section{Identification of Gaseous and Solid Products}

Information on gaseous and solid products of the reaction between $\mathrm{UO}_{2}$ and carbon at the high temperatures (about $2500^{\circ} \mathrm{C}$ ) attained by par ticles in the induction plasma torch is useful for process design and 
scale-up considerations. The gaseous product was identified from the results of analyses of the solid product for uranium, carbon, and oxygen. Solid products were identified by $\mathrm{X}$-ray diffraction analysis.

The ratio of decreases in carbon and oxygen upon conversion of the feed to product ( $\mathrm{g}$-atoms of carbon decrease per $\mathrm{g}$-atom of uranium/g-atoms of oxygen decrease per g-atom of uranium) was $\sim 1.0$ for Runs 15, 16, and 18 . This value for the ratio indicates that the gas eous product of the reaction between $\mathrm{UO}_{2}$ and graphite in an argon-3.2 vol \% hydrogen plasma flame is CO.

$\mathrm{X}$-ray diffraction analysis of the solid-product samples indicates that uranium monocarbide and alpha-uranium dicarbide were present, along with unreacted uranium dioxide (see Table VI later for detailed results). Possibly, alpha-UC 2 was produced in the hot zone of the plasma flame, and quenching of the product particles in the reaction chamber prevented its decomposition to $\mathrm{UC}$ and $\mathrm{C}^{24}$ The following reactions probably occurred:

$$
\begin{aligned}
& \mathrm{UO}_{2}+3 \mathrm{C} \rightarrow \mathrm{UC}+2 \mathrm{CO} \\
& \mathrm{UO}_{2}+4 \mathrm{C} \rightarrow \text { alpha }-\mathrm{UC}_{2}+2 \mathrm{CO}
\end{aligned}
$$

Almost identical $\mathrm{X}$-ray diffraction patterns resulted for product samples from Runs 16 and 18 . In these runs, agglomerates with different carbon contents ( 8.7 and 12.1 wt \% carbon) were fed to the plasma torch at rates 0.9 and $0.06 \mathrm{~kg} / \mathrm{hr}$, respectively. The results suggest that the relative rates of monocarbide and dicarbide formation are independent of feed composition, feed rate, and feed particle size (in the range of 58-107 $\mu \mathrm{m}$ ). The extent of conversion of uranium dioxide to uranium carbides appears to be governed by the temperature level attained by the individual particles.

In a final purification step, the concentration of the uranium dicarbide may be lowered to the desired level by reducing the hyperstoichiometric carbide in a hydrogen atmospher $\mathrm{e}^{25}$ or by converting the dicarbide to monocarbide by reaction with uranium dioxide. ${ }^{26}$ The presence of large amounts of the dicarbide along with the monocarbide may be undesirable in a fuel for a sodium-cooled reactor, because the hyperstoichiometric carbide is decarburized by the stainless steel cladding, and the fuel-to-cladding sodium bond facilitates decarburization. ${ }^{27}$

D. Process Scale-up Considerations

In the induction plasma torch method, since the solids and gas are continuously moving as a dilute suspension at very high velocities, solids do not build up in any portion of the equipment and large-scale equipment can be designed to be critically safe. 
The design characteristics and operating conditions of the induction plasma torch system influence the conversion of oxide to carbide as well as the percentage of carbide spheres in the solid product; probably, yields of carbide spheres will be higher in large units than in small units. Production rates of at least $0.12 \mathrm{lb} / \mathrm{kWh}$ can probably be achieved with more efficient, larger plasma torches than the one used in the present study. A discussion of the economics of plasma torch operation by Dundas and Thorpe 28 indicates that a large-scale unit may possibly be operated economically. 


\section{APPENDIX A}

\section{Preliminary Runs Using Granular Alumina}

In a series of preliminary runs, granular alumina (44-149 $\mu \mathrm{m})$ was fed to the induction plasma torch to determine the operating characteristics of the plasma torch from its ability to spheroidize alumina particles. The granular alumina was used as a stand-in for composite particles of uranium dioxide and graphite.

The independent variables investigated in these preliminary runs included alumina feed rate, power input to the oscillator, gas composition, and gas flow rate. The operating conditions and results for 21 runs with granular alumina are listed in Table III. Granular alumina was introduced from the top of the quartz tube into the plasma zone in all runs except Run IB-4, in which alumina was introduced 1 in. deeper into the plasma zone. Typical granular alumina and typical alumina after one pass through the induction plasma torch in Run IIC-3 are shown in Fig. 8.

Alumina feed rates between 0.6 and $1.2 \mathrm{~kg} / \mathrm{hr}$ had little effect on the percentage of melted particles (e.g., compare the percent melted for Runs IIA-2 and IIA-3 or for Runs IIA- 1 and IB-1), indicating that much higher feed rates may be practical and that the upper limit for feed rates of solids (where the solids start to cool the plasma flame) had not been reached. When power input to the oscillator was increased from 13.5 to $21 \mathrm{~kW}$ while the other operating conditions were maintained constant, the percentage of alumina particles melted increased from 13 in Run IIA- 1 to 57 in Run IIA-2 and 49 in Run IIA-2R.

TABLE III. Operating Conditions and Results of Preliminary Plasma Torch Runs with Granular Alumina

\begin{tabular}{|c|c|c|c|c|c|c|c|c|c|c|c|c|}
\hline \multirow[b]{3}{*}{ Run } & \multirow{3}{*}{$\begin{array}{l}\text { Power } \\
\text { Input to } \\
\text { Oscillator, } \\
\text { kW }\end{array}$} & \multirow{3}{*}{$\begin{array}{c}\text { Alumina } \\
\text { Feed Rate, } \\
\text { kg/hr }\end{array}$} & \multicolumn{5}{|c|}{ Feed Rate of Gas, scfh, through } & \multirow{2}{*}{\multicolumn{3}{|c|}{$\begin{array}{c}\text { Plasma Gas Composition, } \\
\text { vol \% }\end{array}$}} & \multirow{3}{*}{$\begin{array}{c}\text { Reaction } \\
\text { Chamber } \\
\text { Pressure, } \\
\text { psig }\end{array}$} & \multirow{3}{*}{$\begin{array}{l}\text { Percent } \\
\text { of Alumina } \\
\text { Particles } \\
\text { Melted }\end{array}$} \\
\hline & & & \multirow{2}{*}{$\begin{array}{l}\text { Axial } \\
\text { Nozzle }\end{array}$} & \multirow{2}{*}{$\begin{array}{l}\text { Tangential } \\
\text { Nozzle B }\end{array}$} & \multirow{2}{*}{$\begin{array}{l}\text { Tangential } \\
\text { Nozzle C }\end{array}$} & \multirow{2}{*}{$\begin{array}{l}\text { Radial } \\
\text { Nozzle }\end{array}$} & \multirow{2}{*}{$\begin{array}{l}\text { Alumina } \\
\text { Feeder }\end{array}$} & & & & & \\
\hline & & & & & & & & Argon & Nitrogen & Hydrogen & & \\
\hline |A-1 & 13.0 & 0.6 & & 59 & & 74 & 6.8 & 100 & & & -6.4 & 21 \\
\hline $\mid A-2$ & 12.9 & 0.6 & & 59 & & 74 & 6.5 & 100 & & & -5.4 & 3 \\
\hline IA-3 & 13.1 & 0.6 & & 59 & & 74 & 6.5 & 100 & & & -5.4 & 3 \\
\hline IB-2R & 13.3 & 0.6 & & 59 & & 74 & 6.5 & 100 & & & -0.5 & 52 \\
\hline IB-3 & 14.0 & 0.6 & & 59 & & 74 & 8.8 & 100 & & & -5.6 & 15 \\
\hline IB-AC & 13.2 & 0.6 & & 59 & & 74 & 6.5 & 100 & & & -5.4 & 1 \\
\hline$\| A-1$ & 13.5 & 1.26 & & 59 & & 74 & 6.5 & 100 & & & -5.6 & 13 \\
\hline$\| A-2$ & 21.0 & 1.26 & & 59 & & 74 & 6.5 & 100 & & & -5.6 & 57 \\
\hline$\| I A-2 R$ & 21.0 & 1.26 & & 59 & & 74 & 6.5 & 100 & & & -5.6 & 49 \\
\hline $11 \mathrm{~A}-3$ & 21.0 & 0.6 & & 59 & & 74 & 6.5 & 100 & & & -5.4 & 51 \\
\hline IIC-3 & 14.3 & 0.6 & & 59 & & 74 & 6.5 & 96 & & 4 & $\begin{array}{l}-3.4 \\
-3.4\end{array}$ & 89 \\
\hline III-1 & 13.0 & 0.6 & & 59 & & 93 & 6.5 & 100 & & & -4.9 & 23 \\
\hline$\| \mid-2$ & 13.0 & 0.6 & 74 & 59 & & & 6.5 & 100 & & & -4.9 & 42 \\
\hline III-3 & 13.0 & 0.6 & & 59 & 74 & 74 & 6.5 & 100 & & & -4.9 & 7 \\
\hline$|I|-4$ & 13.0 & 0.6 & 59 & & & 74 & 6.5 & 100 & & & -4.9 & 27 \\
\hline
\end{tabular}

Duration of alumina feed for each run was $3 \mathrm{~min}$. Reaction chamber contained air.

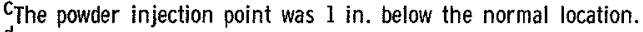

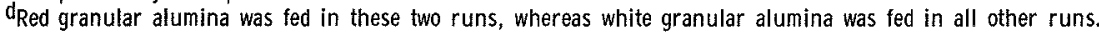




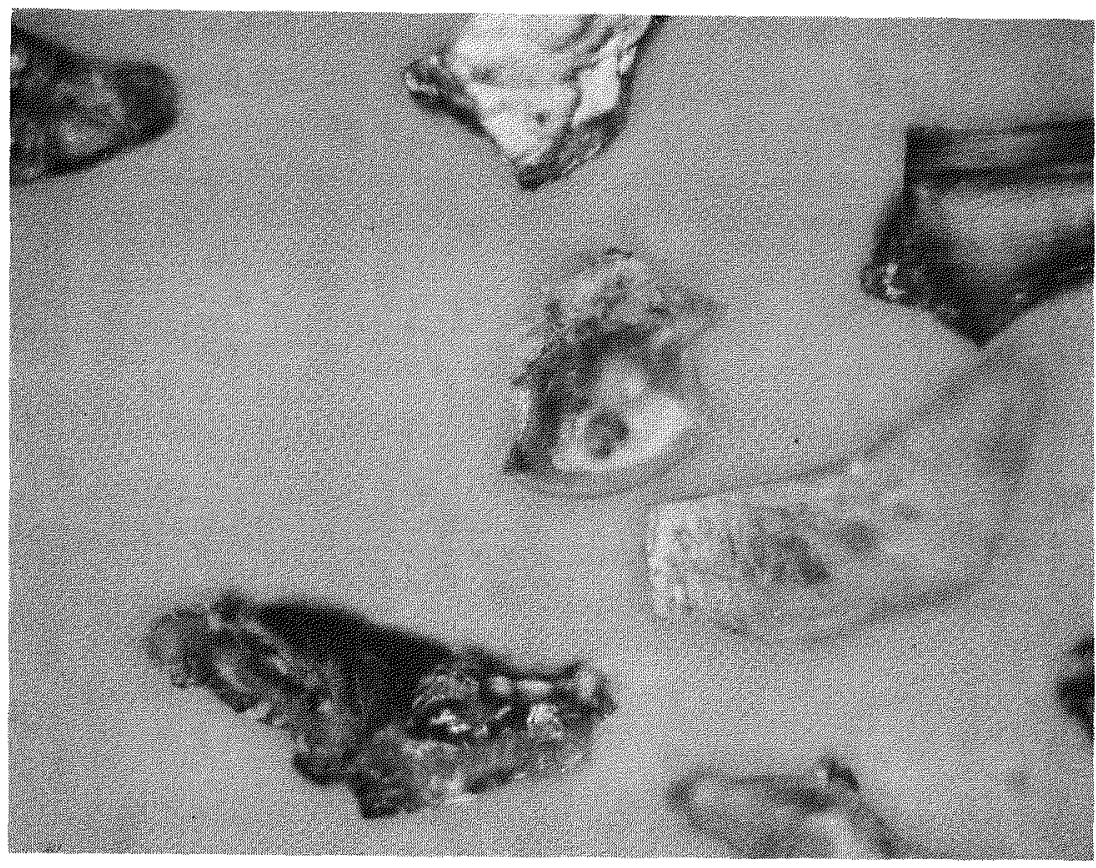

a. Granular Alumina Feed. Mag. 200X.

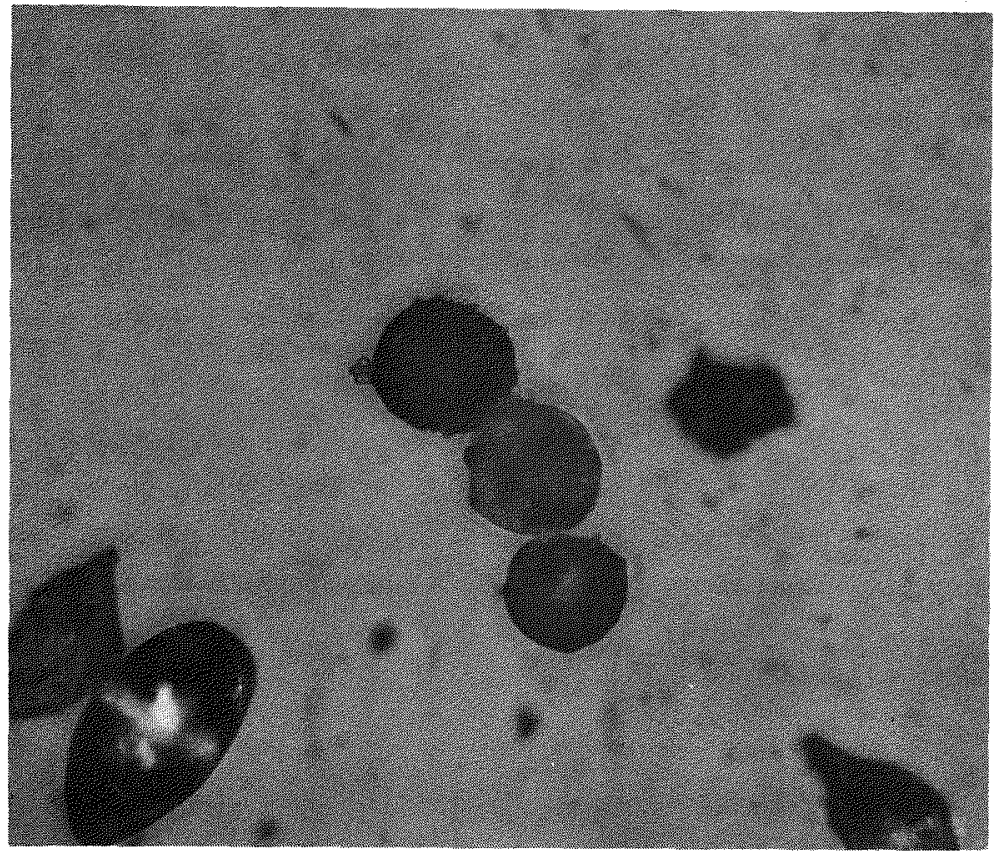

b. Spheroidized Alumina after One pass through the Induction Plasma Torch. Mag. 200X.

Fig. 8. Typical Granular and Spheroidized Alumina (Run IIC-3)

The effect of gas composition on spheroidization of alumina is shown in Table IV. The percentage of melted particles increased from 16 for pure argon plasma (Run IB-1) to 21 for 4 vol \% nitrogen-argon plasma (Run IIC-1), and 89 for 4 vol \% hydrogen-argon plasma (Run IIC-3). 
Spheroidization was fairly uniform for all sizes of the particles $(53-137 \mu \mathrm{m})$ with the hydrogen-argon plasma. With the other two types of plasma, a larger percentage of the smaller particles melted.

TABLE IV. Effect of Diatomic Gas in Argon Plasma on Spheroidization of Granular Alumina

Solid feed rate: $10 \mathrm{~g} / \mathrm{min}$

\begin{tabular}{|c|c|c|c|c|c|c|c|c|}
\hline \multirow[b]{2}{*}{ Run } & \multicolumn{2}{|c|}{$\begin{array}{c}\text { Diatomic Gas } \\
\text { Concentration } \\
\text { in Argon } \\
\end{array}$} & \multicolumn{6}{|c|}{ Particles Melted, \% } \\
\hline & Gas & Vol \% & $137 \mu \mathrm{m}$ & $115 \mu \mathrm{m}$ & $96.5 \mu \mathrm{m}$ & $75 \mu \mathrm{m}$ & $53 \mu \mathrm{m}$ & Total \\
\hline IB - 1 & - & - & 0 & 0 & 2 & 33 & 50 & 16 \\
\hline IIC - 1 & $\mathrm{~N}_{2}$ & 4 & 0 & 2 & 50 & 60 & 60 & 21 \\
\hline IIC -3 & $\mathrm{H}_{2}$ & 4 & 90 & 90 & 100 & 95 & 90 & 89 \\
\hline
\end{tabular}

Increasing the plasma gas flow rate from $140 \mathrm{scfh}$ in Run IA-3 to $159 \mathrm{scfh}$ in Run III- 1 increased the percentage of alumina particles melted from 3 to 23, but a further increase to $210 \mathrm{scfh}$ in Run III-3 decreased the percentage melted to 7 . Changing the gas flow patterns in the plasma had significant effects on the percentage of melted particles. For a constant gas flow rate, using the axial and tangential gas flow patterns in Run III- 2 gave the highest percentage melted, 42 , with the pure argon plasma flame at constant power input to oscillator, but the flame was unstable when there was any significant axial flow. 


\section{APPENDIX B}

\section{Runs with $\mathrm{UO}_{2}$-Graphite Agglomerates}

Agglomerated particles of $\mathrm{UO}_{2}$ and graphite were fed into the tail flame of plasma in 17 runs. The operating conditions are listed in Table V, and the results of analyses of product samples are presented in Table VI.

During the first 11 runs, the reaction chamber contained air. Some graphite was burned. It was observed that the carbon content of the solid product decreased at higher power inputs $(20 \mathrm{~kW})$, lower gas flow rates (132 scfh), and higher hydrogen concentrations in the plasma gas (6 vol \%). The effects of these operating conditions on lowering the carbon content of the agglomerates was analogous to their effects on the percentage of melted granular alumina particles. As was expected, the oxygen content of the product was nearly the same as the oxygen content of the feed, indicating that the hot particles emanating from the torch had reacted with atmospheric oxygen in the reaction chamber.

In the final set, six runs, uranium dioxide and graphite agglomerates were fed into the tail flame formed from argon-3.2 vol \% hydrogen plasma in an inert-argon atmosphere. The results of the final set of runs were discussed in the main body of this report.

TABLE V. Operating Conditions for the Conversion of Uranium Dioxide-Graphite Agglomerates in the Induction Plasma Torch Reactor

Feed point for powder: Tail flame

\begin{tabular}{|c|c|c|c|c|c|c|c|c|c|c|c|c|}
\hline \multirow[b]{4}{*}{ Run } & \multirow{4}{*}{$\begin{array}{l}\text { Power } \\
\text { Input to } \\
\text { Oscillator, } \\
\text { kW }\end{array}$} & \multicolumn{5}{|c|}{ Powder Feed } & \multicolumn{3}{|c|}{ Feed Rate of Gas, scfh } & \multirow{4}{*}{$\begin{array}{l}\text { Hydrogen } \\
\text { in Plasma, } \\
\text { vol \% }\end{array}$} & \multirow{2}{*}{\multicolumn{2}{|c|}{ Reaction Chamber }} \\
\hline & & \multirow{3}{*}{$\begin{array}{c}\text { Duration, } \\
\text { min }\end{array}$} & \multirow{2}{*}{\multicolumn{2}{|c|}{$\begin{array}{l}\text { Concentra- } \\
\text { tion, wt \% }\end{array}$}} & \multirow{3}{*}{$\begin{array}{l}\text { Average } \\
\text { Particle } \\
\text { Size, } \mu \mathrm{m}\end{array}$} & \multirow{3}{*}{$\begin{array}{c}\text { Nominal } \\
\text { Feed Rate, } \\
\text { kg/hr }\end{array}$} & \multirow{3}{*}{$\begin{array}{l}\text { Through } \\
\text { Tangential } \\
\text { Nozzles }\end{array}$} & \multirow{3}{*}{$\begin{array}{l}\text { Through } \\
\text { Radial } \\
\text { Nozzles }\end{array}$} & \multirow{3}{*}{$\begin{array}{l}\text { Through } \\
\text { Solid } \\
\text { Feeder }\end{array}$} & & & \\
\hline & & & & & & & & & & & \multirow[b]{2}{*}{ Atmosphere } & \multirow{2}{*}{$\begin{array}{c}\text { Pressure, } \\
\text { psig }\end{array}$} \\
\hline & & & C & 0 & & & & & & & & \\
\hline 1 & 15.2 & 2 & 8.7 & 12.1 & 107 & 0.9 & 57 & 67 & 8 & 3.2 & Air & -2.5 to 0 \\
\hline 2 & 15.9 & 2 & 8.7 & 12.1 & 107 & 0.9 & 57 & 67 & 7 & 3.2 & Air & -2.5 to 1 \\
\hline 3 & 15.9 & 2 & 8.7 & 12.1 & 107 & 0.9 & 57 & 67 & 10 & 3.2 & Air & 0 \\
\hline 4 & 15.7 & 2 & 8.7 & 12.1 & 107 & 0.6 & 57 & 67 & 8 & 3.2 & Air & 0 \\
\hline 5 & 16.8 & 2 & 8.7 & 12.1 & 107 & 0.9 & 57 & 67 & 8 & 0.0 & Air & -2.5 to 0 \\
\hline 6 & 15.7 & 2 & 8.7 & 12.1 & 107 & 0.9 & 57 & 67 & 8 & 1.5 & Air & 0 \\
\hline 7 & 15.0 & 2 & 8.7 & 12.1 & 107 & 0.9 & 55 & 67 & 8 & 6.0 & Air & 1.0 \\
\hline 8 & 15.4 & 2 & 8.7 & 12.1 & 107 & 0.9 & 57 & 93 & 8 & 3.1 & Air & 0 \\
\hline 9 & 20.0 & 2 & 8.7 & 12.1 & 107 & 0.9 & 57 & 93 & 8 & 3.0 & Air & 1.0 \\
\hline 10 & 15.7 & 2 & 8.7 & 12.1 & 107 & 1.2 & 57 & 67 & 8 & 3.1 & Air & -1.0 \\
\hline 11 & 15.8 & 2 & 8.7 & 12.1 & 107 & 0.9 & 57 & 67 & 8 & 3.1 & Air & 1.0 \\
\hline 12 & 15.9 & 2 & 8.7 & 12.1 & 107 & 0.9 & 57 & 67 & 7 & 3.2 & Argon & 0 to 2.5 \\
\hline 14 & 15.9 & 2 & 8.7 & 12.1 & 107 & 0.9 & 57 & 67 & 7 & 3.2 & Argon & -1.5 to 2.5 \\
\hline 15 & 15.9 & 10 & 8.7 & 12.1 & 107 & 0.9 & 57 & 67 & 7 & 3.2 & Argon & 1.0 \\
\hline 16 & 15.9 & 10 & 8.7 & 12.1 & 107 & 0.9 & 57 & 67 & 7 & 3.2 & Argon & 0.5 to 1.0 \\
\hline 17 & 15.9 & 60 & 5.7 & 13.0 & 107 & 0.9 & 57 & 67 & 7 & 3.2 & Argon & 0.4 to 1.8 \\
\hline 18 & 15.9 & 60 & 12.1 & 13.2 & 58 & 0.06 & 57 & 67 & 7 & 3.2 & Argon & 0.3 to 1.1 \\
\hline
\end{tabular}

During Run No. 13, a porcelain insulator supporting a choke coil in the Lepel high-frequency generator broke, causing rf arcs. The run was prematurely terminated, and hence the operating conditions are not tabulated above. 
TABLE VI. Analysis of Product Samples

\begin{tabular}{|c|c|c|c|c|c|c|}
\hline \multirow[b]{2}{*}{ Run } & \multicolumn{2}{|c|}{$\begin{array}{c}\text { Carbon, } \\
\text { wt } \%\end{array}$} & \multirow{2}{*}{$\begin{array}{c}\text { Oxygen,a } \\
\text { wt } \%\end{array}$} & \multicolumn{3}{|c|}{$\mathrm{X}$-ray Diffraction Analysis $\mathrm{C}$} \\
\hline & Totalb & Free & & $\mathrm{UO}_{2}$ & $\mathrm{UC}$ & Alpha- $U C_{2}$ \\
\hline 1 & 6.3 & & & & & \\
\hline 2 & 6.5 & & 10.7 & & & \\
\hline 3 & 6.2 & & & & & \\
\hline 4 & 5.0 & & & & & \\
\hline 5 & 5.5 & & & & & \\
\hline 6 & 5.3 & & 12.1 & & & \\
\hline 7 & 5.0 & & & & & \\
\hline 8 & 5.6 & & & & & \\
\hline 9 & 4.9 & & 12.4 & & & \\
\hline 10 & 5.3 & & & & & \\
\hline 11 & 5.8 & & 10.5 & & & \\
\hline 12 & & & & Major & Intermediate & Intermediate \\
\hline 14 & 6.2 & & 9.6 & Major & Intermediate & Intermediate \\
\hline 15 & 5.7 & 1.7 & 8.2 & Major & Minor & Minor \\
\hline 16 & 5.7 & 1.7 & 7.9 & Major & Intermediate & Intermediate \\
\hline 17 & 3.4 & 1.2 & 11.0 & Major & Minor & Minor \\
\hline 18 & 8.4 & 3.6 & 7.4 & Major & Intermediate & Intermediate \\
\hline
\end{tabular}

average of two analyses.

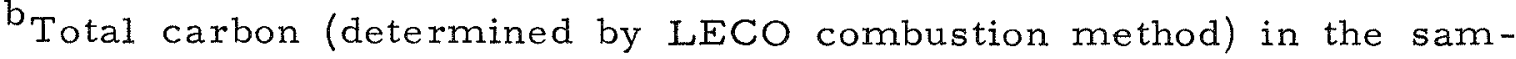
ple, including free carbon (determined by a gravimetric method, which includes dissolution of the sample in dilute nitric acid) and the carbon in $\mathrm{UC}$ and $\mathrm{UC}_{2}$. The total carbon value for the sample is used in the analysis for oxygen content by combustion at $925^{\circ} \mathrm{C}$ of the sample.

$\mathrm{c}_{\text {Estimated concentration ranges: }}$ Major $=\sim 50$ wt $\%$; intermediate $=50$ to $30 \mathrm{wt} \% ; \operatorname{minor}=30$ to $10 \mathrm{wt} \%$. The compounds present are identified by the X-ray diffraction patterns generated by a sample of about $100 \mu \mathrm{g}$ held in a capillary tube. The presence or absence of a compound is decided by visual ins pection, and by comparison of the patterns generated with standard patterns of these compounds. Since the relative concentrations of these compounds are estimated by assessing the intensity of the patterns present, the values for the concentrations are only qualitative estimates. 


\section{APPENDIX C \\ Performance of Equipment Components}

Equipment component performance pertinent to the further development of the induction plasma torch reactor for the conversion of uranium dioxide to uranium carbide and to the development of large-scale units is summarized in the following discussion.

\section{Induction Plasma Torch Performance}

During the preliminary series of runs, granular alumina was introduced from the top of the quartz tube directly into the plasma zone. The quartz tube and the hot gas exit nozzle at the bottom of the tube became coated with alumina particles in about $12-15$ min of operation (four to five runs, each of $3-$ min duration). The presence of any foreign particles on the tube wall promotes arcing of the rf current to the tube, causing the tube to break. Hence, it was necessary to clean the tube after every fourth or fifth run.

In the first run to convert $\mathrm{UO}_{2}$ to $\mathrm{UC}$ (not reported in Table V), agglomerates of $\mathrm{UO}_{2}$ and graphite powder were fed directly (like the alumina) into the plasma arc of argon with 3 vol $\%$ hydrogen. The power input to the oscillator was relatively low $(13 \mathrm{~kW})$. The gas flow rates and flow patterns were such that a stable plasma was formed. However, soon after the flow of solids was started, the quartz tube cracked. A possible explanation is that this breakage might have been caused by localized overheating due to increase in heat transferred to the quartz tube when the agglomerates were present. The increase in the heat transfer may be attributable to the higher emissivity of the plasma when it contains the agglomerates than when it contains the granular alumina or no solids.

During the subsequent runs, the uranium dioxide-graphite agglomerates were fed into the tail flame downstream from the plasma zone (through orifices in the exit nozzle below the plasma-forming region). The absence of bulk of solids in the plasma zone allowed longer-duration runs to be made, although the solids were exposed to the high temperatures for shorter times than when they were fed directly into the plasma zone.

As the $\mathrm{UO}_{2}$-graphite agglomerates were fed, a thin coating of fine powder formed on the inside of the brass double flange that holds the plasma torch and the quartz-plate insulator. Typical coating is shown in Fig. 9. The fines might have been generated by breakage of large agglomerates due to rapid evolution of $\mathrm{CO}$ product during conversion, and coating might have occurred due to electrostatic phenomena and/or thermal phenomena near the flange. 


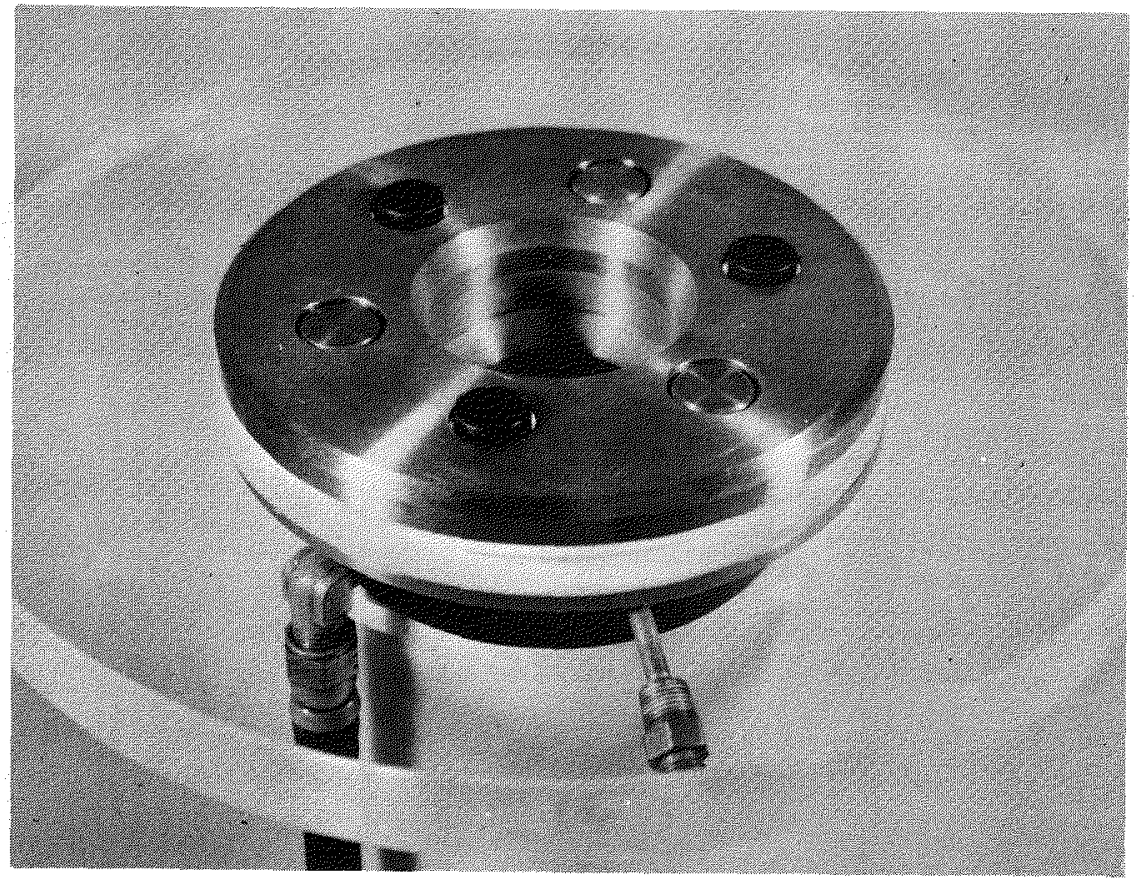

a. Torch Assembly before Run

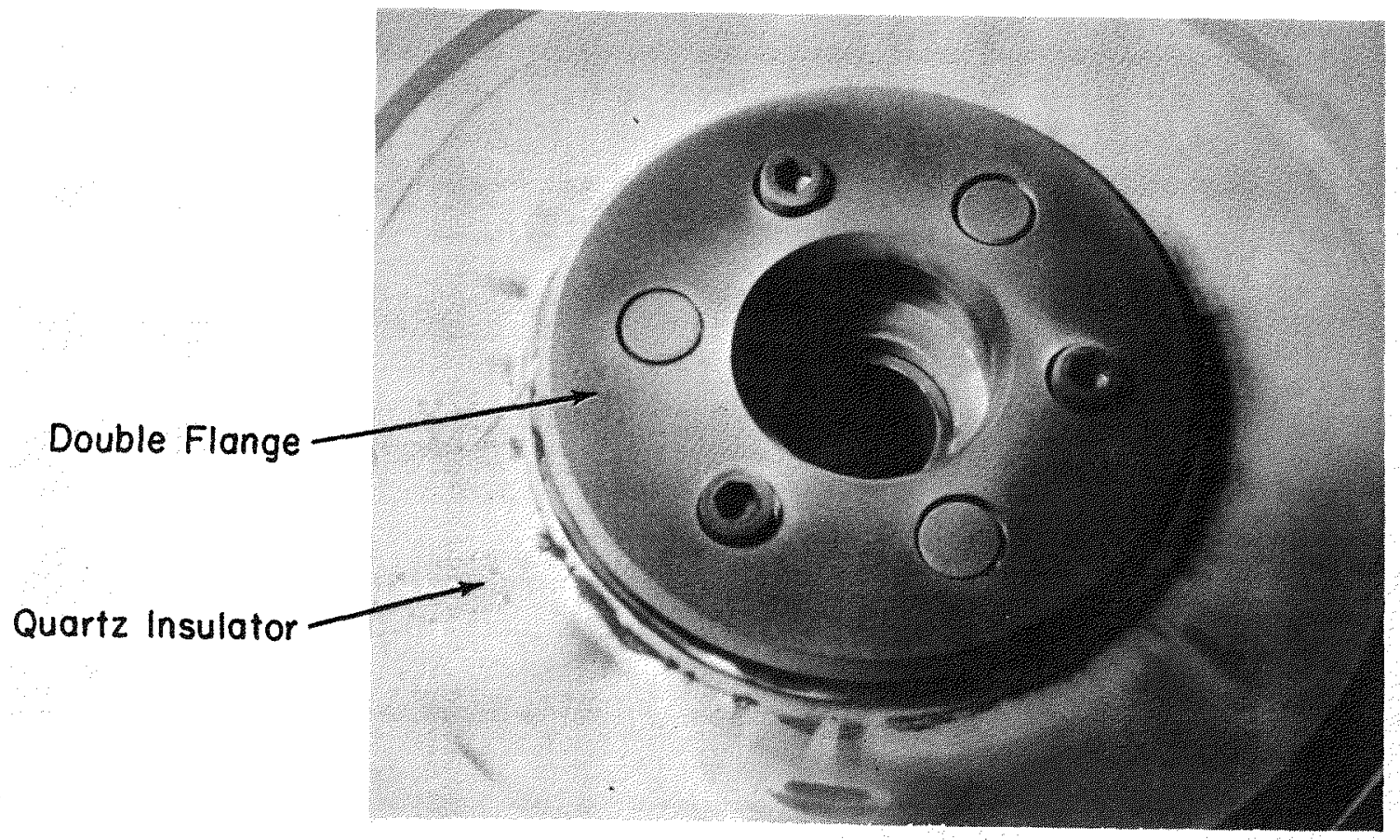

b. Torch Assembly after Run

Fig. 9. Coating of Fines on Double Flange Holding Plasma Torch and Quartz Plate Insulator during a Run 
The performance of the induction plasma torch indicates that the designs of the plasma containment tube, the solids-feed orifices, and the auxiliary flanges should be improved for further development or scale-up of the conversion process.

\section{Mullite Guide Tube}

A mullite guide tube (5.6 in. ID, 6.1 in. OD, 27 in. long) was installed below the plasma torch to contain the tail flame and guide the particles into the product receiver. In the absence of the guide tube, powder fed into the plasma (both axially and radially) did not fall through the center of the tail flame. Instead, most of the powder was held up on horizontal ledges in the reaction chamber, and only a minor amount reached the product receiver.

The top of the mullite guide tube broke occasionally. Typical breakage of the top portion of the mullite tube is shown in Fig. 10. This breakage might have been caused by localized overheating of the guide tube.

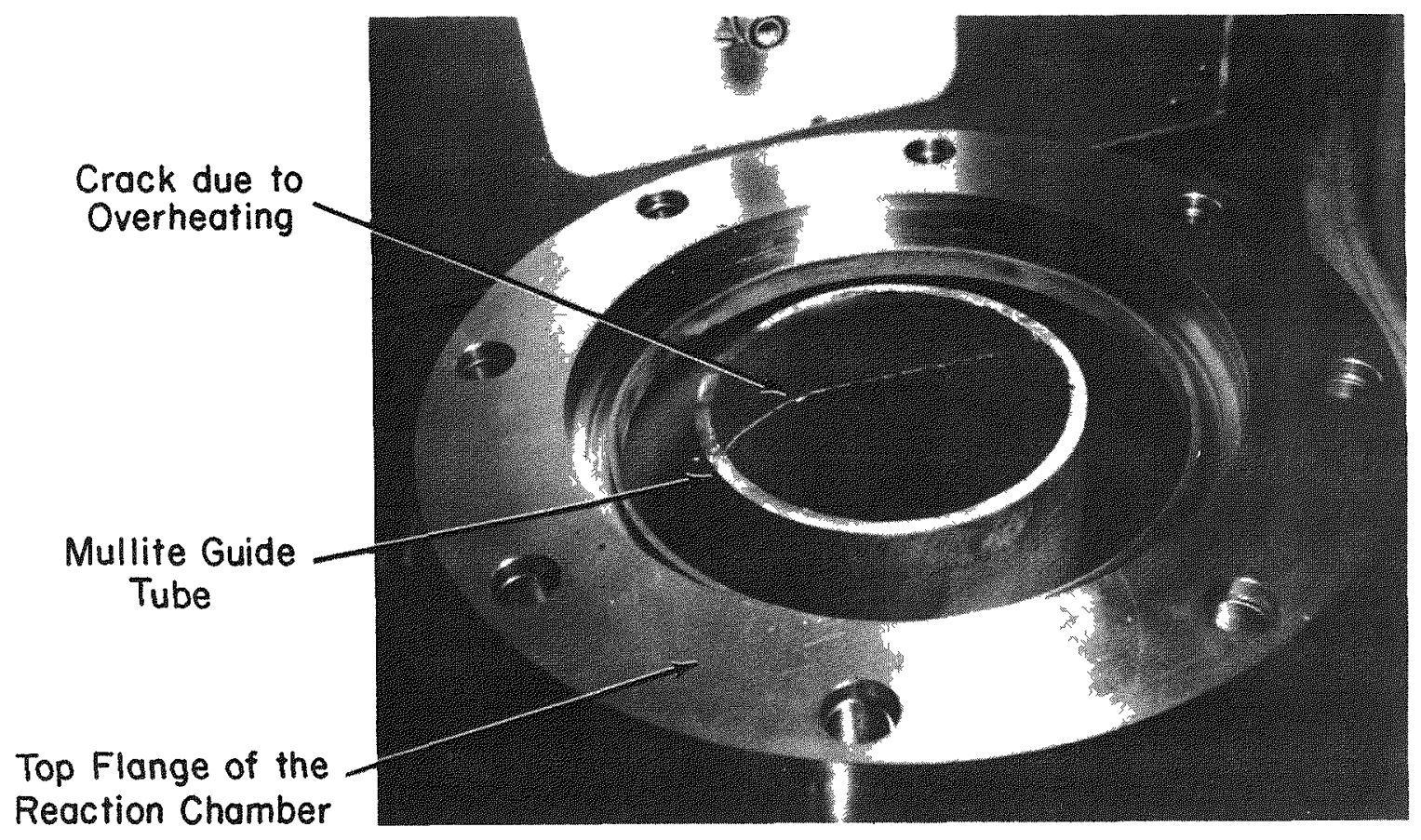

Fig. 10. Top Portion of Mullte Tube, Showing Breakage due to Overheating

To determine the approximate temperatures reached by the mullite tube during a run, marks were made longitudinally on outside wall of the tube with heat-sensitive pencils (Tempilstiks*) before a run. The tube was inspected after a run. The discolorations of the Tempilstik markings indicated that the top $18.5 \mathrm{in}$. of the guide tube had reached temperatures

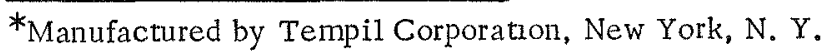


greater than $500^{\circ} \mathrm{F}\left(255^{\circ} \mathrm{C}\right)$ and that the top 21 in. had reached temperatures greater than $300^{\circ} \mathrm{F}\left(149^{\circ} \mathrm{C}\right)$. An approximate value of the maximum temperature of the tube was calculated by assuming that the net heat gain (the difference between heat gained by radiation and forced convection from the plasma flame to the tube and heat lost by radiation and natural convection from the tube to the reaction chamber) resulted in a linear temperature profile along the length of the tube. The temperature gradient was calculated to be $80^{\circ} \mathrm{F} / \mathrm{in}$. , and the highest temperature (at the top of the pipe) to be $1480^{\circ} \mathrm{F}$ $\left(804^{\circ} \mathrm{C}\right)$. Further design would have to be done for a guide tube operated at these temperatures for further development or for scale-up of the conversion process. 


\section{ACKNOW LEDGMENTS}

We acknowledge the support and continued interest in this investigation by R. C. Vogel and D. S. Webster. Contributions were made to this investigation by J. T. Holmes, who participated in the procurement and installation of the plasma-torch equipment; T.R. Johnson, who participated during the initial runs; and P. A. Nelson, who participated during installation of the plasma-torch equipment and during the initial runs. Thanks are extended to $M$. J. Steindler for his interest in this investigation, to $R$. V. Schablaske and his associates for $\mathrm{X}$-ray diffraction analyses of samples, to P.D. Hunt for analysis of samples for total carbon, and to the Analytical Group for analyses of samples for carbon, oxygen, and uranium. 


\section{REFERENCES}

1. S. Strausberg, Preparation of UC by Carbothermic Reduction of $U_{3} \mathrm{O}_{8}$, NAA-SR-10486 (June 1965).

2. J. T. Holmes, J. R. Pavlik, P. A. Nelson, and J. E. A. Graae, A Hightemperature, Fluidized-bed Process for Converting Uranium Dioxide to Uranium Monocarbide, ANL-7482 (Nov 1968).

3. E. A. Coppinger, Formation of $\mathrm{UO}_{2}$-Carbon Mixtures and Carbide or Nitride Fuel Material in a Spray Reactor, BNUL-843 (Dec 1968).

4. E. A. Coppinger and B. M. Johnson, Formation of Carbide and Nitride Fuel Material in a Spray Reactor, Am. Nuc1. Soc. Trans. 12 (2), 437 (1969).

5. N. Parkinson and L. E. Russell, "The Preparation and Fabrication of Carbides: A Review of United Kingdom Experience," Proceedings of the International Symposium on Ceramic Nuclear Fuels, American Ceramic Society, May 3-8, 1969, Washington, D.C., pp. 51 to 59.

6. R. Egalon, R. Vankille, and M. Willemyns, Purification of Gases for Anmonia Manufacture - Removal of Carbon Monoxide by Cuprammonium Carbonate Solutions, Ind. Eng. Chem. 47, 887-897 (1955).

7. H. F. Mark, J. J. McKatta, Jr., and D. F. Othmer, Encyclopedia of Chemical Technology, Vo1. 4, p. 438, John Wiley and Sons, New York (1964).

8. L. V. Jones, D. Ofte, P. A. Tucker, and L. J. Wittenberg, "High Density Plutonium Dioxide Microspheres for a Reactor Fuel," Proceedings of the Third Conference on Nuclear Reactor Chemistry, Held in Gatininburg, Tennessee, Oct. 9-11, 1962, TID-7641, p. 300 (1962).

9. L. V. Jones and L. J. Wittenberg, "Plutonium Reactor Fuels Research Program at Mound Laboratory," in Plutonium as a Power Reactor Fuel, Proceedings of American Nuclear Society Topical Meeting, Richland, Washington, Sept. 13 \& 14, 1962, HW-75007, p. D2.8 (Dec 1962).

10. C. C. Browne and R. E. Latta, "Coated Fuel Particle Development and Evaluation, Ceramic-Matrix Fuels Containing Coated Particles," Proceedings of the Symposium at Battelle Memorial Institute, Nov 5-6, 1962, TID-7654, p. 291.

11. H. J. Hedger and A. R. Hal1, Preliminary Observations on the Use of the Induction-Coupled Plasma Torch for the Preparation of Spherical Powder, Powder Metallurgy, No. 8, 65 (1961).

12. R. T. Tremper, $R-F$ PZasma Microspheroidization of Ceramics, UCRL-17896 (Dec 1967).

13. G. D. White and D. C. O'Rourke, Method of Making Spherical Actinide Carbide, U.S. Patent 3,070,420 (Dec 25, 1962).

14. J. O. Gibson and R. Weidman, Chemical Synthesis via the High Intensity Are Process, Chem. Eng. Progr. 59, 53 (1963).

15. D. M. Helton, A Preliminary Study on Uranium Carbide Synthesis, Using a PZasma Jet, ORNL-TM-872 (May 1964).

16. D. W. Sturge and R. T. Smyth, Forming of Refractory Spheroids by Plasma Jet and the Development of a Plasma Fumace, Part I, NP-10941

(Dec 6, 1961). 
17. D. W. Sturge and R. T. Smyth, Forming of Refractory Spheroids: Part II, DP-Report-147 (Jan 1963).

18. T. A. J. Jacques and D. W. Sturge, The Development of the Plasma Arc Furnace for Fuel Melting, DP-Report-148 (Jan 1963).

19. H. Bildstein, The Different Methods of Spheroidizing, Ber. Deut. Keram. Ges. 41, 108 (1964). Translated by Kresge-Hooker Science Library Services, MLM-1480 ( $t r$ ).

20. Merle L. Thorpe, Induction Plasma Heating: System Performance, Hydrogen Operation and Gas Core Reactor Simulator Development, a report prepared under Lewis Work Order NAS3-9375 by TAFA Division, Humphreys Corporation, Concord, N.H. (Jan 11, 1968).

21. R. F. Baddour and R. S. Timmins, The Application of Plasmas to Chemical Processing, M.I.T. Press, Cambridge, Massachusetts (1967).

22. R. Ainsley, B. R. Harder, N. Hodge, R. G. Sowden, D. B. White, and D. C. Wood, "Carbides as Reactor Fuels: Preparation from Oxides and Sintering Characteristics," in New Nuclear Materials including NonMetallic Fuels, Vol. I, pp. 349 to 376, International Atomic Energy Agency, Vienna, 1963.

23. T. B. Lindemer, M. D. Allen, and J. M. Leitnaker, Kinetics of the Graphite-Uranium Dioxide Reaction from $1400^{\circ}$ to $1756^{\circ} \mathrm{C}$, J. Am. Ceramic Soc. 52(5), 233 (May 1969).

24. J. J. Katz and E. Rabinovitch, The Chemistry of Uranium, p. 222, McGrawHill Book Company, Inc. (1951).

25. B. R. Harder, J. Read, and R. G. Sowders, The Reduction and Sintering of Hyperstoichiometric Carbides in Hydrogen, J. Nuc1. Mater. 17, 203-214 (1965).

26. J. R. Piazza and M. J. Sinnott, High Temperature Phase Equilibria in the System Carbon-Oxygen-Uranium, J. Chem. Eng. Data 7(4), p. 451 (1962)。

27. R. B. Holden, Ceramic Fuel Elements, p. 86, Gordon and Breach Science Publishers, New York (1966).

28. P. H. Dundas and M. L. Thorpe, Economics and Technology of Chemical Processing with Electric Field Plasmas, Chem. Eng. 76(14), 123

(June 30, 1969). 